\title{
Consumer Use of Mobile Banking (M-Banking) in Saudi Arabia: Towards an Integrated Model
}

\section{Abdullah M. Baabdullah}

Department of Management Information Systems, Faculty of Economics and Administration, King Abdulaziz University, Jeddah, Kingdom of Saudi Arabia

Email: baabdullah@kau.edu.sa

\section{Ali Abdallah Alalwan}

Amman College of Banking and Finance, Al-Balqa Applied University, Amman, Jordan Email: alwan.a.a.ali@gmail.com; Alwan_jo@bau.edu.jo

\section{Nripendra P. Rana}

Emerging Markets Research Centre (EMaRC), School of Management, Swansea University Bay Campus, Fabian Way, Swansea SA1 8EN, UK

Email: nrananp@gmail.com

\section{Hatice Kizgin}

Emerging Markets Research Centre (EMaRC), School of Management, Swansea University Bay Campus, Fabian Way, Swansea SA1 8EN, UK Email: hatice.kizgin@swansea.ac.uk

\section{Pushp Patil}

Emerging Markets Research Centre (EMaRC), School of Management, Swansea University Bay Campus, Fabian Way, Swansea SA1 8EN, UK

Email: papushp@gmail.com 


\title{
Consumer Use of Mobile Banking (M-Banking) in Saudi Arabia: Towards an Integrated Model
}

\begin{abstract}
Mobile banking is one of the most promising technologies that has emerged in recent years and could prove to have considerable value to both banks and customers. Thus, this study recognises the need to test the main factors that could predict the use of mobile banking as well as how using such a system could contribute to both customer satisfaction and customer loyalty. The conceptual model of this study combines two models (i.e. UTAUT2 and the D\&M IS Success Model). A questionnaire survey was conducted to collect the required data from convenience sampling of Saudi bank customers. The main factors - performance expectancy, price value, facilitating conditions, hedonic motivation, habit, system quality and service quality - were found to have a significant impact on actual use behaviour. This study was cross-sectional, therefore future studies should implement longitudinal studies in order to re-collect the findings. Further, this study adopted convenience sampling of Saudi M-Banking users. This may adversely impact the issue of generalisability to the whole population. The gap in the MBanking literature in Saudi Arabia would be bridged by proposing a comprehensive conceptual model that scrupulously clarifies the use of M-Banking from the perspective of Saudi users. Furthermore, this study would consider the adoption of numeric data in order to inferentially analyse them using SEM. This in turn would assist in generalising the findings to the whole Saudi population.
\end{abstract}

Keywords: Mobile Banking, UTAUT2, IS Success Model, Saudi Arabia

\section{Introduction}

The current advancements in the field of mobile technologies have yielded profound modifications and incessant resonating in the use of mobile banking in the financial sector (e.g. Alalwan et al., 2017; Gupta, 2013; Lin, 2011; Rana et al., 2017; Shaikh and Karjaluoto, 2015; Zhang et al., 2018; Zhou, 2012b). M-Banking is an application of m-commerce delivered by financial institutions or banks that permits its users to perform financial transactions remotely by adopting a mobile device like Personal Digital Assistants (PDA), mobile phone or smartphone (Al-Jabri and Sohail, 2012). This service is implemented to make payments such as checking banking accounts, making transactions, and transferring money (Alkhaldi, 2016; Arcand et al., 2017; Slade et al., 2015a, 2015b). M-Banking is unique as it has different yet advanced levels of system quality, information quality, and service quality when compared with previous e-banking services such as computers, kiosks, and laptops (Tam and Oliveira, 2017). For instance, having a mobile would enable customers to do banking transactions without the need for physical fixed machines. Thus, M-Banking 
enables users to connect with the cyber world at any moment and trade simultaneously, and this in turn has changed the ways of using banking services (Aboelmaged and Gebba, 2013).

This new technology has considerably reduced the level of financial fees compared with conventional banking services. For instance, according to international money transfer service Azimo, users of M-Banking in the UK save up to $£ 7 \mathrm{bn} /$ year in financial fees by using M-Banking apps, which assist them in switching money more efficiently and evade overdraft charges (BBC, 2017). Therefore, British Telecommunications (2017) indicated that novel mobile-only banks (e.g. Monzo) are empowering users to gain better control over their finances. Accordingly, studying the factors that influence the use of M-Banking is a necessity for individuals and/or the society in general, as it could save 'billions' in charges (BBC, 2017). For the aforementioned reasons, persons tend to adopt M-Banking and shifting to deal with the banks that use M-Banking's services. Recognising the importance of adopting MBanking in order to gain competitive advantage in the markets, competing banks around the world have invested about $\$ 115$ billion with the aim of increasing the level of M-Banking adoption. The hope is that by providing them with this advanced technology, it will increase consumer satisfaction and strengthen their loyalty, preventing them from turning to other competing banks (Alalwan et al., 2017; Chung and Kwon, 2009; Ganguli and Roy, 2011).

In the Kingdom of Saudi Arabia (KSA), there is an increasing interest in engaging mobile systems in all aspects of citizens' and customers' daily life. Such interest could be attributed to the new trends adopted by the Saudi government to invest more in new and innovative applications that make people's lives much easier. This interest is clearly observed in what has been said to be Saudi Arabia's Vision 2030. Further, both the public and private sectors have projected about $\$ 2.14$ billion to build and introduce new smart systems (Exportgov, 2018). As for mobile technology, the number of mobile phone subscribers is very high in KSA where the mobile penetration rate has reached about $140 \%$ over the first quarter of 2017 (Albawaba, 2017). Further, about 22.85 million Saudi customers have used their mobile phone to access Internet services (Statista, 2018a). According to a survey conducted and published by Statista (2018b), about $53 \%$ of customers are interested in using online banking transactions. On the other hand, based on a report published by Albawaba (2017), 50\% of Saudi bank customers expressed their intention to switch banks because of the low level of mobile and online banking solutions offered by their current provider. Moreover, mobile platforms have been reported by $40 \%$ of Saudi customers as the most favourable and convenient banking channel to access banking services (Albawaba, 2017). This, in turn, could 
raise a question about the effectiveness and feasibility of investment in mobile banking channels to match Saudi customers' requirements as well as reduce the bank switching rate of Saudi customers.

Furthermore, a considerable number of studies in different contexts have focused on the factors that impact the use of M-Banking (e.g. Akturan and Tezcan (2010) in Turkey; Faria (2012) in Portugal; Hanafizadeh et al. (2014) in Iran; Afshan and Sharif (2016) in Pakistan; Koenig-Lewis et al. (2010) in Germany; Masrek and Razali (2014) in Malaysia; Alalwan et al. (2016) in Jordan; Sharma et al. (2017) in Oman; Xiong (2013) in China). Within the context of Saudi Arabia, numerous studies have examined M-Banking usage among customers (e.g. Al-Husein and Sadi, 2015; Al-Jabri and Sohail, 2012, Alkhaldi, 2016; Alsheikh and Bojei, 2014; Hidayat-ur-Rehman, 2014). Moreover, in order to examine the factors that impact use of M-Banking, researchers used various models. For example, Sripalawat et al. (2011) used Technology Acceptance Model (TAM); Al-Husein and Sadi (2015) implemented an extended TAM; Lee (2009) integrated Theory of Planned Behaviour (TPB) and TAM; Al-Jabri and Sohail (2012) embraced Diffusion of Innovation Theory (DIT); Yu (2012) employed UTAUT; Alalwan et al. (2017) adopted UTAUT2; and Tam and Oliveira (2017) used the Delone and Mclean (D\&M) IS Success Model.

However, this study differs from the aforementioned studies as it expands the range of factors that might impact the use of M-Banking within the context of Saudi Arabia. This is done through combining two models i.e. the Unified Theory of Acceptance and Use of Technology (UTAUT2) of Venkatesh et al. (2012) and the D\&M IS Success Model of Delone and Mclean (2003) for examining M-Banking. The espousal of this conceptual model would contribute to the current literature review as there is no up-to-date study that combines UTAUT2 and D\&M IS Success Model in one model in order to examine the factors that impact the use of M-Banking. Furthermore, the gap in the M-Banking literature in Saudi Arabia would be bridged by proposing a comprehensive conceptual model, which scrupulously clarifies the use of M-Banking from the perspective of Saudi users. Furthermore, this study would consider the adoption of numeric data in order to inferentially analyse them using SEM. This in turn would assist in generalising the findings to the whole Saudi population. 


\section{Literature review}

Identifying the factors that impact the level of actual use of a technology has been perceived as an essential aim for changing the characteristics of a given technological service to make its adoption more attractive (Baabdullah et al., 2018; Kuisma et al., 2007). With regard to MBanking, a considerable number of studies (e.g. Al-Jabri and Sohail, 2012; Baptista and Oliveira, 2015; Choudrie et al., 2018; Lee and Chung, 2009; Yu, 2012; Zhou, 2011) in various contexts (e.g. Saudi Arabia, South Korea, Taiwan and Mozambique) examined the variables that might impact M-Banking use. Studies that investigate the use of M-Banking have embraced a number of theories, such as Diffusion of Innovation Theory, UTAUT2, and the DeLone and Mclean IS Success Model, to tackle this aim. As such, Al-Jabri and Sohail (2012) relied on Diffusion of Innovation Theory to analyse the data of 330 actual M-Banking users within the domain of Saudi Arabia and indicated that relative advantage, compatibility and observability positively impacted the actual use of Saudi customers, while trialability and perceived risk negatively influenced the actual usage.

Furthermore, Lee and Chung (2009) adopted the DeLone and Mclean IS Success Model in order to examine users' satisfaction regarding M-Banking within the domain of South Korea. Thus, after using questionnaire to collect data from 276 M-Banking customers, the analysed data indicated that system quality and information quality of M-Banking service influences users' trust and satisfaction. However, they found that interface design quality of M-Banking does not impact the dependent factors of trust and satisfaction. Indeed, when there is a positive impact of satisfaction, the use of the service would be positively impacted as well. This logic inferential is based on the arguments of the DeLone and Mclean IS Success Model itself. To go into more detail, within the D\&M IS Success Model, DeLone and Mclean (2003, p.23) argued that "use" and "user satisfaction" are "closely interrelated". Although "Use" should come before "user satisfaction" in "a process sense"; however, the successful and positive experience with "use" would result in higher "user satisfaction" in a causative way. Likewise, higher levels of "user satisfactions" would result in maximising "intention to use" and eventually "use" (DeLone and Mclean, 2003, p.23). Therefore, based on this logic, the positive impact of system quality, information quality of M-Banking service mentioned in Lee and Chung's (2009) findings on satisfaction can be safely extended to include the use of M-Banking.

Moreover, through relying on the UTAUT model, Yu (2012) examines the variables impacting the usage of M-Banking within the context of Taiwan. After analysing the data 
collected from 441 participants, the findings indicate that behavioural intention, perceived self-efficacy and facilitating conditions positively influence the actual usage of Taiwanese users. Likewise, Baptista and Oliveira (2015) used UTAUT with cultural moderators in order to investigate the factors affecting M-Banking within the domain of Mozambique. More specifically, they combined the UTAUT model of Venkatesh (2003) with cultural moderators extracted from Hofstede (2003). After analysing the numeric data by using structural equation modelling, they reported that facilitating conditions, habit and behavioural intention significantly and positively affect the use of M-Banking. More importantly, they found that cultural moderators significantly moderate the strength of the relationship between the habit and behavioural intention as independent variables on the one hand and the use of $\mathrm{M}$ Banking, which is the dependent variable, on the other hand. Among distinctive cultural moderators, collectivism, uncertainty avoidance, short term and power distance were proved to have the most important moderating effect. Other studies that relied on UTAUT for examining the role of M-Banking include Bhatiasevi (2016) and Zhou et al. (2010).

Recently, there have been several studies that have tested the main factors and aspects that could predict customers' intention, attitudes, and behaviour towards mobile banking (i.e. Asongu and Nwachukwu, 2018; Malaquias et al., 2018; Mehrad and Mohammadi; 2017; Sampaio et al. 2017; Singh and Srivastava, 2018; Shareef et al. 2018; Tam and Oliveira, 2017; Warsame and Ireri, 2018). This clearly explains that mobile banking is still a subject worthy of research and study. In this regard, Malaquias et al. (2018) assured the importance of tracking the fluctuation in usage rate of mobile banking over time. Based on the results from their longitudinal study, Malaquias et al. (2018) also added that by spending time using mobile banking, Brazilian banking customers are more likely to have a positive perception of certain aspects of the system such as trustworthiness, task characteristics, social influence, and ease of use. Likewise, Shareef et al. (2018) have studied customer acceptance of mobile banking over three main phases: static, interaction, and transaction. Their results largely supported the impact of perceived ability to use and perceived functional benefit over three phases of mobile banking adoption.

Over the developing countries, another recent study was also conducted by Warsame and Ireri (2018) who supported the moderation impact of gender on the association between two factors from UTAUT: performance expectancy and effort expectancy with Iranian customers' intention to use mobile banking. Aspects of culture (religion) were also supported by Warsame and Ireri (2018) to moderate the impact of customers' intention on the actual use of 
mobile banking in Iran. In Iran as well, Mehrad and Mohammadi (2017) have tested how the recommendations and suggestions coming from people surrounding the customers could predict their intention to use mobile banking. According to Mehrad and Mohammadi (2017), word of mouth has been proven to have a significant impact on customers' attitudes which, in turn, influence the actual use behaviour. In India, Singh and Srivastava (2018) found that customers' willingness to adopt mobile banking is positively correlated with the level of customers' perception toward aspects pertaining to ease of use, security, and self-efficacy.

Tam and Oliveira (2017) went further than the adoption of mobile banking by considering the impact of such a system on customer satisfaction. They empirically supported the idea that customers are more likely to be pleased about mobile banking if they perceive a high-quality system, information, and service quality in using mobile banking. By the same token, Sampaio et al. (2017) argued that customers seem to be more satisfied with mobile banking if they actually experience the main benefits of using such a system. Sampaio et al. (2017) also added that those customers who are pleased with their experience in using mobile banking are more likely to be loyal toward their banks for providing such innovative channels.

Within the context of Saudi Arabia, according to the World Bank (2017), mobile cellular subscriptions (per 100 people) have risen 158\% between the year of 2000 and 2016. More specifically, according to The EY GCC Digital Banking Report (2015), 15\% of banking customers adopt M-Banking in Saudi Arabia, and furthermore, 34\% of Saudi users are satisfied with the using of M-Banking. From the modest figures of using M-Banking and satisfaction levels when using M-Banking, there is a need to identify the reasons why the adoption of M-Banking in Saudi is still behind optimal expectation levels, although there has been an increase in the number of mobile subscriptions within Saudi Arabia. Indeed, the EY GCC Digital Banking Report (2015) stated that the slow adoption of M-Banking is due to an unintuitive user experience, the fact the it is not in real time, slow transaction speeds, the fact that it is not tailored to fulfil personal needs, the non-availability of preferred channels, and difficulty to access. Interestingly, these factors, which limit the successful adoption of mobile technology (i.e. M-Banking), as mentioned by the EY GCC Digital Banking Report (2015), can be classified, based on DeLone and Mclean IS Success Model, under only the following categories: deficiencies related to system quality and deficiencies related to information quality. That is to say, while the quality of a given technological service (i.e. M-Banking) should provide acceptable levels of "usability, availability, reliability, adaptability, and response time" (DeLone and Mclean, 2003, p.24), using M-Banking in Saudi Arabia showed 
a lack of responsive times (not real time and slow action speed), and lack of availability (nonavailability of preferred channel and difficulty to access) as reported by The EY GCC Digital Banking Report (2015).

With regard to the level of information quality, Saudi M-Banking is supposed to reveal an ability to be "personalized, complete, relevant, easy to understand, and secure" (DeLone and Mclean, 2003, p.25). However, Saudi M-Banking was not personalised as it was not tailored to fulfil personal needs, and it is also difficult to understand as it requires an unintuitive user experience (the EY GCC Digital Banking Report, 2015). However, in relation to the issue of service quality, the EY GCC Digital Banking Report (2015) did not mention deficiencies relating to service quality. In another study, Alkhaldi (2016) indicated that the lack of a proper infrastructure has hampered the Saudi adoption of M-Banking on a wider scale. As such, insufficient networks in the Saudi countryside, the low rate of mobile diffusion to the banking sector, the modest mobile usage for distinctive bank services, and the insufficiency of necessary legal regulations, which aim to raise the service quality of M-Banking, constitute objective parameters that limit proper espousal of M-Banking in Saudi Arabia. From the aforementioned findings of Alkhaldi (2016), it can be seen that the study focused on service quality and system quality without focusing on issues related to information quality.

In order to examine the factors that affect the successful use of M-Banking in Saudi Arabia, there is an intellectual requirement to examine the DeLone and Mclean IS Success Model in its entelechy in order to get comprehensive knowledge about the topic. Furthermore, this study would consider merging the DeLone and Mclean IS Success Model with the Unified Theory of Acceptance and Use of Technology (UTAUT2). As such, the DeLone and Mclean IS Success Model would enable the researcher to measure the success of the M-Banking service within the context of Saudi Arabia on the one hand, whereas UTAUT2 would identify the factors that are responsible for this success on the other hand.

Within this study, independent variables are service quality, information quality, system quality, performance expectancy, effort expectancy, hedonic motivation, social influence, price value, habit, and facilitating conditions, and the aforementioned variables impact on use (the dependent variable). Furthermore, this study would examine the impact of use as an independent variable on satisfaction and loyalty of Saudi customers. This model discards the issue of behavioural intention due to the heavy use of M-Banking. 
Indeed, combining the two models is unprecedented in any study within the context of Saudi Arabia. Accordingly, this study would bridge the gap in the current literature. Furthermore, from a theoretical point of view, testing UTAUT2 on different contests is recommended by Venkatesh et al (2012). In addition, with regard to the Delone and Mclean IS Success Model, it is only focused on e-technological services; hence, there is a need to measure it on certain m-technological services (i.e. M-Banking) on a particular domain (i.e. Saudi Arabia). From a practical point of view, pinpointing the variables that influence the usage of M-Banking in Saudi Arabia would increase the capacity of decision makers in applying proper efficient strategies for increasing the usage of M-Banking though controlling and manipulating the independent variables. This is economically important in the light of the governmental policies in diversifying the revenues away from the heavy reliance on oil resources. To be more specific, the overall contribution of the information and communications technology (ICT) to the whole gross domestic product (GDP) is $6 \%$, and if oil revenue is excluded, the ICT would contribute $10 \%$ of Saudi GDP. Hence, examining the factors that impact the use of M-Banking is essential from an economic point of view in order to increase msubscriptions, and this in turn would raise the revenue gained from the ICT sector (CITC, 2015).

Furthermore, in light of increasing the number of competing banks in Saudi Arabia, such as Riyadh, Rajhi, NCB, SAMBA and SABB, embracing strategies that ensure customer loyalty is essential for getting competitive advantage in the market (Shaikh and Karjaluoto, 2015). Accordingly, this study would include customer loyalty as a dependent variable that is influenced by customer satisfaction and customer usage. Indeed, customer loyalty is essential because it constitutes a parameter that limits the tendency of customers to switch his/her use of M-Banking from one bank to another and from using a certain mobile to another mobile, and from using one network to another (Ganguli and Roy, 2011; Lee et al., 2001; Lin and Wang, 2006; Oppong et al., 2014). In other words, the customer would be loyal to one bank and one network such as STC, Zain or Mobily when doing M-Banking. As a result, the companies that maintain a high level of customer loyalty would increase their sustainable competitive edge and eventually their profits, which is indeed the core aim for providing all new technologies (Oppong et al., 2014). 


\section{Conceptual model and Hypotheses Development}

The conceptual model of this study combines two models (i.e. UTAUT2 and the D\&M IS Success Model) in order to identify the factors that affect consumer use of M-Banking in Saudi Arabia. As can be seen in figure 1, independent factors that are extracted from the UTAUT2 model include performance expectancy (PE), effort expectancy (EE), hedonic motivation $(\mathrm{HM})$, price value $(\mathrm{PV})$, habit $(\mathrm{HT})$, social influence $(\mathrm{SI})$, and facilitating conditions (FC)) (Baabdullah et al., 2018; Dwivedi et al., 2017a). Also, independent variables extracted from the D\&M IS Success Model include three factors (i.e. service quality, information quality, and system quality). Regarding dependent variables, this study adopts the effect of all previous independent variables over use variable, which belongs to the two models (Dwivedi et al., 2016). Furthermore, this study adopts satisfaction as the dependent variable that is influenced by the use variable, and this factor is extracted from the D\&M IS Success Model. Finally, this study adopts the loyalty variable as a dependent variable, which is influenced by use and satisfaction. As both UTAUT2 and the D\&M IS Success Model do not mention a loyalty variable, this addition of loyalty constitutes a contribution to this study. The behavioural intention variable is excluded from this study, although it was mentioned in both the UTAUT2 and D\&M IS Success Model. Dismissing behavioural intention in this model comes as a result of the extensive use of M-Banking internationally and within the context of Saudi Arabia. Thus, this dismissal is based on practical reasons. Furthermore, interestingly, behavioural intention explained that the intention to use a technological service should be done when a service is still new in the markets (DeLone and Mclean, 2003). However, the loyalty variable examines the level of commitment to the same brand and repeated use of the same service (i.e. M-Banking) over time, which cannot be done unless there is an actual use of service (Dwivedi and Irani, 2009; Dwivedi et al., 2017a; Oppong et al., 2014). In other words, behavioural intention precedes use, while loyalty comes after use. Hence, from a logical point of view, there is a rational reason for not gathering both variables in one conceptual model because these variables take place at different times. 


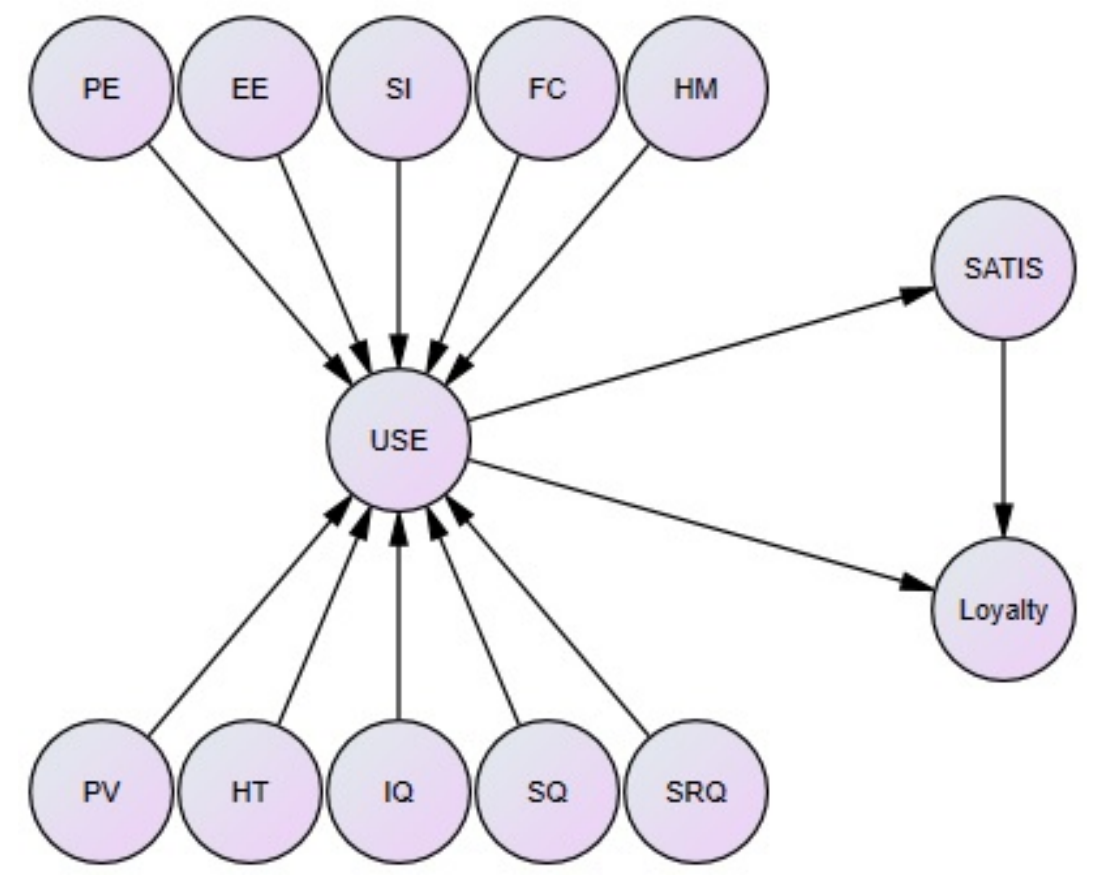

Figure 1: Conceptual Model (Adopted from Delone and Mclean, 2003; Venkatesh et al., 2012)

[PE: Performance Expectancy, EE: Effort Expectancy, SI: Social Influence, FC: Facilitating Conditions, HM: Hedonic Motivation, PV: Price Value, HT: Habit, IQ: Information Quality, SQ: System Quality, SRQ: Service Quality, USE: Usage, SATIS: Satisfaction]

\subsection{Performance Expectancy (PE)}

$\mathrm{PE}$ is defined as "the degree to which an individual believes that applying the technology will help him or her to attain gains in job performance" (Venkatesh et al., 2003, p.447). Regarding M-Banking, users believe that using this service will result in changing the nature of banking, navigation patterns, number of site visits, and number of transactions executed (Bhatiasevi, 2016; Dwivedi et al., 2017a, 2017b; Martins et al., 2014; Zhou et al., 2010). Furthermore, based on UTAUT, both Bhatiasevi (2016) and Zhou et al. (2010) concluded that PE significantly influences the continuous use of M-Banking.

The influence of the role of PE and its equivalents (such as perceived relative advantage and perceived usefulness) on the level of actual usage of M-Banking services has been mentioned in a number of studies (e.g. Brown et al., 2003; Sripalawat et al., 2011; Zhang et al., 2018). Brown et al. (2003) reported that perceived relative advantage positively influenced the level of actual usage of M-Banking. Likewise, studies that adopted TAM (e.g. Sripalawat et al., 2011) indicated that perceived usefulness positively impacted the use of M-Banking. Moreover, despite focusing on M-Technologies in general instead of M-Banking, Park et al. (2007) reported, after analysing the data collected from 221 respondents, that PE significantly 
impacted the level of use of M-Technologies. Considering the aforementioned studies, this study hypothesises that:

H1: PE positively enhances the use of M-Banking in Saudi Arabia.

\subsection{Effort Expectancy (EE)}

EE can be defined as "the extent of ease connected with the use of a system" (Venkatesh et al., 2003, p.450). Users feel connected to technologies that are convenient and simple to use (Alalwan et al., 2017; Ozturk et al., 2016; Shareef et al., 2017). With regard to M-Banking and after using UTAUT, Oliveira et al. (2014), Yu (2012) and Zhou et al. (2010) asserted the important role of EE on the level of usage among users. The easy accessibility of a technology tends to motivate users, making them highly inclined to adopt the technology (Dwivedi et al., 2017a, 2017b; Oliveira et al., 2014). Thus, when updating a given technological service automatically, users should not experience difficulty or complexity in using the technology; otherwise, their usage will plummet significantly (Liébana-Cabanillas et al., 2017; Yiu et al., 2007; Yu, 2012). As evaluated by Shaikh and Karjaluoto (2015), the level of usage is significantly affected when M-Banking technology updates lead to changes in the level of ease in using the service. Thus, it can be hypothesised that:

\section{H2: EE positively enhances the use of M-Banking in Saudi Arabia.}

\subsection{Social Influence (SI)}

SI is "the extent to which an individual perceives that important others believe he or she should apply the new system" (Venkatesh et al., 2003, p.450). The preferences and values of society, including family members, friends, relatives, neighbours and other users of the technology, tend to change the perceptions and viewpoints of users profoundly (Alsheikh and Bojei, 2014; Rana et al., 2015). This particularly occurs when the current users of a given technology are influenced by the shift of their peers and families from using one technological service to another (Baptista and Oliveira, 2015; Dwivedi et al., 2017a, 2017b). In an age where social media and word of mouth dominate the cyber world (Dwivedi et al., 2018; Kapoor et al., 2018; Roy et al., 2018), the effects of social relationships can either maintain or increase the usage of a given technological service or divert users towards a socially acceptable new technology (Al-Somali et al., 2009; Williams et al., 2015). Indeed, users might switch their usage of non-socially acceptable technology to socially acceptable technology in order to get higher levels of social interaction and integration (Jahya, 2004). 
Indeed, the positive role of SI in the usage of M-Banking was affirmed by Al-Husein and Sadi (2015) within the context of Saudi Arabia. Thus, as per the discussion:

H3: SI positively enhances the use of M-Banking in Saudi Arabia.

\subsection{Facilitating Conditions (FC)}

FC is "the degree to which an individual believes that an organizational and technical infrastructure exists to support the use of the system" (Venkatesh et al., 2003, p.453). A number of studies have indicated the positive influence of FC on the level of usage among users (e.g. Dwivedi et al., 2017a, 2017b; Rana et al., 2016; Shaikh and Karjaluoto, 2015; Yu, 2012; Zhou et al., 2010). The capacity to $\log$ in to personal accounts, the ability to transfer money from one account to another, and a high level of compatibility support the use of MBanking (Shaikh and Karjaluoto, 2015).

People's perceptions are influenced by technological infrastructure and organisational development, which can motivate them to continue using a given service (Dwivedi et al., 2017a, 2017b; Lee and Chung, 2009). According to feedback from 343 participants, Jordanian customers are more motivated to use M-Banking facilities when they get complete support and favourable conditions (Alalwan et al., 2017). The ability of people to browse the Internet and get access to online banking facilities has influenced their intentions to use the technology. The level of compatibility that users feel during the use of technology tends to increase their propensity to use the technology. Due to the development of technology in Saudi Arabia, it can be said that the immense support and convenience of using the Internet can influence customers to opt for online banking systems. Thus, from the discussion, the underlying hypothesis can be highlighted as follows:

H4: FC positively enhances the use of M-Banking in Saudi Arabia.

\subsection{Hedonic Motivation (HM)}

$\mathrm{HM}$ is "the fun or pleasure derived from using a technology, and it has been shown to play an important role in determining technology acceptance and use" (Venkatesh et al., 2012, p.161). When customers find that the technology they are using gives them happiness, fun, entertainment, comfort, enjoyment, satisfaction, and pleasure, they will tend not to change their use of the technology to another competing technology (Alalwan et al., 2015; Baabdullah, 2018a; Koenig-Lewis et al., 2010). The effect of HM on the usage of M-Banking has been mentioned in a number of studies (e.g. Alalwan et al., 2017; Dwivedi et al., 2017a, 
2017b; Zhou et al., 2010; Yu, 2012). This discussion can be related to the Saudi Arabian context, and the hypothesis thus states:

H5: HM positively enhances the use of M-Banking in Saudi Arabia.

\subsection{Price Value (PV)}

PV is defined as "the consumers' cognitive trade-off between the perceived benefits of the applications and the monetary cost for using them" (Venkatesh et al., 2012, p.161). During the course of using a technological service, users tend to compare the prices they paid for the technology and the discounts they might get from the continuous use of the technology (Alalwan et al., 2014; Baabdullah, 2018b; Al-Sukkar, 2005; Laukkanen and Lauronen, 2005). Thus, they will tend to increase their level of usage when they are rewarded by discounts (Laukkanen and Lauronen, 2005). However, in the context of Internet banking and MBanking, consumers will radically become reluctant to continue using a technology when the providers of the service increase its prices (Njenga and Ndlovu, 2012). In such circumstances, the users of the technology tend to switch their usage to a competing service (Laukkanen, 2007; Raleting and Nel, 2011). As indicated by Alalwan et al. (2017), when the PV level is higher, customers become more enthusiastic about continuing to use a technology. It should be ensured that the benefits derived from the technology use are greater than the monetary costs paid by the customers for continuing to use the technology (Lee et al., 2012). Accordingly, users who are unable to pay the required money for continuing the use of upgraded technology (such as M-Banking) fail to show interest in continued use. Based on this assumption, it can be stated that:

\section{H6: PV positively enhances the use of M-Banking in Saudi Arabia.}

\subsection{Habit (HT)}

HT is "the extent to which people tend to perform behaviors automatically because of learning" (Venkatesh et al., 2012, p.161). Thus, it can be seen that habit is associated with the automaticity and repeated performance of an action (Lee, 2009). Understanding HT is essential for increasing the use of a technology (Changchit et al., 2017; Gupta, 2013; Limayem et al., 2007). Regarding M-Banking, Huili and Zhong (2011) asserted that repeated use of M-Banking gradually increases the additivity in using this service compared to EBanking. Thus, in the Saudi Arabian context, it can be said that:

H7: HT positively enhances the use of M-Banking in Saudi Arabia. 


\subsection{System Quality}

System quality is defined as a measure of the success of a service from a technical point of view (Delone and McLean, 2003, p.10). Examples of the technical characteristics that are measured by system quality include usability, availability, reliability, adaptability, and response time (Delone and McLean, 2003, p.24). Thus, it can be deduced that system quality covers a number of distinctive characteristics that can be measured as independent variables. That is to say, a given technological service might have availability but might not enjoy reliability (Laforet and Li, 2005). Hence, system quality has neither conclusive nor immaculate conditions; rather, it focuses on the technical level of a given service (Lee and Chung, 2009). This refers to the efficiency and accuracy of the technical system (Shannon and Weaver, 1998).

Customers feel highly motivated to adopt and use systems that can provide the maximum technical efficiency and expected accuracy (Peters et al., 2016; Upadhyay and Jahanyan, 2016). The direct link between system quality and technology use was effectively evaluated by Delone and McLean (2003), who used an IS success model. In the case of M-Banking, the benefits that the customers will get by using the facility will help them to grow interested in it, and thus the propensity to use the technology will increase due to the sensitivity of using online financial services (Zhou, 2011). This sensitivity demands the highest degrees of efficiency and accuracy in the provided technology. Based on the above analysis, this study proposes that:

H8: System quality positively enhances the use of M-Banking in Saudi Arabia.

\subsection{Service Quality}

Service quality refers to "the overall support delivered by the service provider" in a way that reveals assurance, empathy, and responsiveness (Delone and McLean, 2003, p. 25). This factor indicates that the technology used by the customers is delivered by the providers with a high level of security/privacy, practicality, design/aesthetics, enjoyment, and sociality (Arcand et al., 2017; Shareef et al., 2014; Shih and Fang, 2006). This support can be given through various information technology providers such as Internet service providers, new organisational units, and IS departments (Casalo et al., 2007; Shih and Fang, 2004). The significant role of service quality in the use of Internet banking was affirmed by Jun and Cai (2001). Within the context of M-Banking, there are three sides that assure service quality (i.e. banks or financial institutions, mobile providers, and the network company through which the 
user browses the Internet (Changchit et al., 2017; Lee and Chung, 2009). Service quality is essential in increasing the usage as the users of M-Banking are customers of these three providers and, accordingly, if there is low and weak support of users, a higher turnover from the provided service would occur, and one or more of the providers would lose (Jaruwachirathanakul and Fink, 2005). If people find that the online banking facilities are providing them with better privileges and opportunities with attractive schemes, then their usage of M-Banking will increase (Faria, 2012; Zhou, 2011). Thus, the hypothesis states:

H9: Service quality positively enhances the use of mobile banking in Saudi Arabia.

\subsection{Information Quality}

Information quality is a "measure" that "measures semantic success, which is the success of the information in conveying the intended meaning" (Delone and Mclean, 2003, p. 10). In other words, information quality measures the fitness for use of the information provided by a technological service through capturing the content issued (Changchit et al., 2017; Han et al., 2016; Kim et al., 2009). According to Kahn et al. (2012), the content provided by a given service does have various characteristics (i.e. accessibility, reputation, believability, value added, understandability, objectivity, interpretability, completeness, concise representation, free of error and timeliness, consistent representation, appropriate amount of information, and personalisation). Providing these benchmarks aims to tackle the needs of users in order to increase their level of usage. Chae et al. (2002) found that information quality significantly influences the use of mobile Internet in general. More specifically, Lee and Chung (2009) found that information quality positively impacts the usage of M-Banking within the context of South Korea.

H10: Information quality positively enhances the use of mobile banking in Saudi Arabia.

\subsection{Usage, Satisfaction, and Loyalty}

Usage "measures everything from a visit to a Web site, to navigation within the site, to information retrieval, to execution of a transaction" (Delone and McLean, 2003). This study examined the impact of usage over user satisfaction and user loyalty.

User satisfaction is "the extent to which an application helps the user creates value for the firm's internal or external customers" (Delone and Mclean, 2003, p.20). This variable measures "our customers' opinions of our e-commerce system" (Delone and Mclean, 2003, p.25). This means that the user satisfaction is only perceived after using the service and, in 
order to measure the impact of using a service on satisfaction, it is essential to measure the whole cycle of customer experience from information retrieval (Chu et al., 2009; Chung and Kwon, 2009; Dwivedi et al., 2013). This can be fulfilled through measuring user satisfaction at the various steps of purchasing, payment, getting a receipt, and service. Indeed, the concepts of use and user satisfaction are closely associated (Saleem and Rashid, 2011). In detail, in the process sense, use precedes user satisfaction, whereas having high positive experience when using a service would result in higher satisfaction among users in the casual sense (Delone and McLean, 2003; Laforet and Li, 2005). Likewise, maximising the level of user satisfaction would eventually result in higher level of actual usage (Tam and Oliveira, 2017). Within the context of M-Banking, Chung and Kwon (2009) undertook a multi-group analysis of information system success instruments and found that usage does positively impact user satisfaction. The positive impact of usage would increase when there is successful systems quality, information quality, and service quality; furthermore, the positive effect of usage over satisfaction is moderated by trust (Chung and Kwon, 2009). Based on the aforementioned analysis, this study supposes that:

\section{H11: Usage positively enhances customers' satisfaction in Saudi Arabia.}

Customer loyalty is a pattern of users' behaviour where they become committed to the brands they use and repetitively use the same service technology without switching to another like service as time passes (Oppong et al., 2014). Furthermore, loyal customers tend to use the same service irrespective of the issue of price (Ganguli and Roy, 2011). There are a number of strategies followed by companies in order to increase customer loyalty, for example providing incentives such as free gifts and samples (Lee et al., 2001). Interestingly, a company tends to increase the loyalty to its services through increasing the level of usage of its services through enhancing service quality, information quality, and systems quality (Laforet and Li, 2005; Saleem and Rashid, 2011). Through increasing the level of usage, customers will get used to the given service, and this in turn will develop unintentional motivation to be loyal to the product (Lin and Wang, 2006). Indeed, Ganguli and Roy (2011) and Oppong et al. (2014) asserted that usage would increase the level of M-Banking. Hence, based on the aforementioned analysis, this study proposes:

\section{H12: Usage positively enhances customers' loyalty in Saudi Arabia.}

As Delone and McLean (2003) asserted that there is a close interrelation between usage and user satisfaction in the casual sense, this study would consider the impact of satisfaction on 
loyalty. A company tends to increase the level of user satisfaction as a main policy for achieving the ultimate aim (i.e. increasing the loyalty to its brand) (Lin and Wang, 2006; Saleem and Rashid, 2011). Furthermore, within the domain of information technology services in the banking sector, Lin and Wang (2006) stressed the importance of getting user satisfaction as an antecedent step for getting their loyalty. Furthermore, Lee et al. (2001) recognised the relationship between satisfaction and loyalty when using mobile services in France. Therefore, this study proposes that:

\section{H13: Satisfaction positively enhances customers' loyalty in Saudi Arabia.}

\section{Methodology}

For the purpose of this study, data were collected from the six largest cities in the KSA [Riyadh, Jeddah, Mecca, Medina, Al-Ahsa, and Ta'if] to achieve more generalisability and to cover a large portion of the Saudi community. However, due to the absence of a reliable list of Saudi bank customers and their addresses, convenience sampling was conducted to collect the required data using a questionnaire survey allocated to 700 Saudi banks customers who have used and adopted mobile banking services. Over the period between May and August 2017, 700 Saudi banking customers were handed a paper questionnaire to be filled. Researchers used different methods to approach this number of participants. For example, good number of questionnaires was allocated via banking staff. However, to reach adequate response rate, researchers have visited participants at their work places either in private or public sector along some visits to the universities students and staff.

The main constructs of UTAUT2 were measured using items proposed by Venkatesh et al. (2012) while the scale of Dabholkar (1996); Delone and Mclean (2003); Kim et al. (2004); Shamdasani et al. (2008) and Zhou (2011) was adopted to measure three constructs: system quality, service quality, and information quality. The five most common mobile banking services [Balance Enquiries and downloaded bank statements, fund transfers, requesting a cheque book or bank certificates, paying bills, request an increase in credit card(s) limit or pay any balance due] introduced by Saudi banks were also considered to measure the actual usage behaviour. Customer's satisfaction was measured by items from Anderson and Sullivan (1993); Kohli et al. (2004); Lee and Chung (2009); and Rod et al. (2009). Items of customer loyalty were derived from Selnes and Hansen (2001); Lee and Chung (2009); and Zeithaml et al. (1996). A seven-point Likert scale was applied to measure the main constructs of the conceptual model except actual usage, which was tested used anchors including never, once a 
year, several times a year, once a month, several times a month, several times a week, several times a day (Venkatesh et al., 2012).

It is worth indicating that all research questions were translated into Arabic based on the back translation method suggested by Brislin (1976). In addition, to ensure a high degree of validity and reliability, the researchers had conducted a pilot study with 30 staff at King Abdulaziz University. Most of those respondents claimed that the language used was clear and the length of the questionnaire was appropriate as well. Cronbach's coefficient alpha was also tested to ensure a good degree of construct reliability, and all constructs were found to have an acceptable value higher than 0.70 as suggested by Nunnally (1978).

\section{Results}

Out of 700 questionnaires distributed, 429 were returned and found valid to be subjected for further analyses. About $59 \%$ of respondents are male while $41 \%$ are female. The vast majority of respondents were noted to be within the age groups 21-29 (55\%) and 30-39 (21\%). Most of the respondents have a bachelor's degree (44\%), followed by those who have a high school degree (19\%). About $51.2 \%$ of participants were noted as working within the governmental sector while about $(21 \%)$ have a job in the private sector. The largest number of respondents (44.2\%) has an income level between 8,001 and 14,000 Saudi Riyals.

A two-stage approach of structural equation modelling (SEM) was applied to validate the current study model and test the research hypotheses. At the first stage, the measurement model (confirmatory factor analyses) was tested to assure adequate level of model fitness as well as constructs validity and reliability. Then, the main research hypotheses were tested at the second stage (structural model). As seen in Table 1, a number of the fit indices of the measurement model were not found to be within their acceptable level (GFI: Goodness-of-Fit Index $=0.841$; AGFI: Adjusted Goodness-of-Fit Index=0.0.741; CFI: Comparative Fit Index=0.901; CMIN/DF: Normed Chi-Square $=4.125$; NFI: Normed-Fit Index $=0.881$; and RMSEA: Root Mean Square Error of Approximation=0.085). Therefore, the model had to be revised by dropping the most problematic items [FC4, H4, USE4, USE5, SQ5, IQ4, IQ5, and SATIS5], especially those that had factor loading less than 0.50 or those that had higher residual values (see Table 2 and Appendix). After dropping all the problematic items, the revised model was tested again and was believed this time to have adequate level of model 
fitness as all fit indices were observed as follows: GFI $=0.901$; $\mathrm{AGFI}=0.821 \mathrm{NFI}=0.951$; CFI=0.971; and RMSEA=0.066 (Hair et al., 2010; Tabachnick and Fidell, 2007).

Table 1: Results of Measurement Model

\begin{tabular}{|l|l|l|l|}
\hline \multicolumn{1}{|c|}{ Fit indices } & \multicolumn{1}{c|}{ Cut-off point } & \multicolumn{1}{c|}{ Initial measurement model } & Modified measurement model \\
\hline CMIN/DF & $\leq 3.000$ & 4.125 & 2.154 \\
\hline GFI & $\geq 0.90$ & 0.841 & 0.901 \\
\hline AGFI & $\geq 0.80$ & 0.741 & 0.821 \\
\hline NFI & $\geq 0.90$ & 0.881 & 0.951 \\
\hline CFI & $\geq 0.90$ & 0.901 & 0.971 \\
\hline RMSEA & $\leq 0.08$ & 0.085 & 0.066 \\
\hline
\end{tabular}

Table 2: Standardized Regression Weights

\begin{tabular}{|c|c|c|c|c|c|}
\hline Construct & Measurement Items & Estimate & Construct & Measurement Items & Estimate \\
\hline \multirow[t]{4}{*}{$\mathrm{EE}$} & EE1 & .866 & \multirow[t]{3}{*}{ SI } & SI1 & .977 \\
\hline & EE2 & .855 & & SI2 & .928 \\
\hline & EE3 & .877 & & SI3 & .973 \\
\hline & EE4 & .898 & \multirow[t]{3}{*}{ USE } & USE1 & .872 \\
\hline \multirow[t]{3}{*}{ FC } & $\mathrm{FC} 1$ & .993 & & USE2 & .881 \\
\hline & FC2 & .878 & & USE3 & .839 \\
\hline & FC3 & .631 & \multirow[t]{4}{*}{ SQ } & SQ1 & 967 \\
\hline \multirow[t]{3}{*}{$\mathrm{PV}$} & PV1 & .887 & & SQ2 & .773 \\
\hline & PV2 & .691 & & SQ3 & .674 \\
\hline & PV3 & .867 & & SQ4 & .953 \\
\hline \multirow[t]{4}{*}{ PE } & PE1 & .909 & \multirow[t]{3}{*}{ IQ } & IQ1 & .933 \\
\hline & PE2 & .825 & & IQ2 & .883 \\
\hline & PE3 & .863 & & IQ3 & .909 \\
\hline & PE4 & .806 & \multirow[t]{3}{*}{ SRQ } & SRQ1 & .980 \\
\hline \multirow[t]{3}{*}{ HT } & HT1 & .888 & & SRQ2 & .972 \\
\hline & HT2 & .743 & & SRQ3 & .970 \\
\hline & HT3 & .756 & \multirow[t]{4}{*}{ SATIS } & SATIS1 & 918 \\
\hline \multirow[t]{3}{*}{ HM } & HM1 & .848 & & SATIS2 & .851 \\
\hline & HM2 & .684 & & SATIS3 & .875 \\
\hline & HM3 & .830 & & SATIS4 & .821 \\
\hline \multirow[t]{3}{*}{ Loyalty } & Loyalty1 & .960 & & & \\
\hline & Loyalty 2 & .909 & & & \\
\hline & Loyalty3 & .948 & & & \\
\hline
\end{tabular}

All retained items were also subjected to tests for construct reliability and validity. Both composite reliability (CR) and average variance extracted (AVE) were considered in this instance (Anderson and Gerbing, 1988). As seen in Table 3, the CR values for all constructs were noticed to be above 0.70 (Fornell and Larcker, 1981). The largest CR value was recorded for Use followed by Satisfaction while the lowest value was for Hedonic Motivation. As for the AVE values, all constructs have an acceptable value of AVE higher than 0.50 as suggested by Fornell and Larcker (1981) and Hair et al. (2010). The highest 
value of AVE was for Use followed by Satisfaction while the lowest value was found in the case of Habit.

Prior to going further in the structural model analyses, there was a necessity to apply Harman's single-factor test (1976) to avoid any problem pertaining to the common method bias. Thus, 13 latent constructs with their unremoved items were downloaded to Harman's single-factor test provided in SPSS 22. The yielded results in this regard indicated that no single factor was able to emerge, while less than $42.847 \%$ of variance was recorded by the first factor. This value is less than the recommended one $(<0.50)$ (Podsakoff et al., 2003). Therefore, it seems that there was no problem regarding the issue of common method bias. 
Table 3: Construct Validity and Reliability

\begin{tabular}{|c|c|c|c|c|c|c|c|c|c|c|c|c|c|c|c|}
\hline & CR & AVE & SRQ & $\mathrm{PV}$ & SQ & $\mathrm{FC}$ & $\mathrm{EE}$ & $\mathrm{PE}$ & HT & $\mathrm{HM}$ & IQ & SI & SATIS & USE & Loyalty \\
\hline SRQ & 0.896 & 0.720 & 0.849 & & & & & & & & & & & & \\
\hline $\mathrm{PV}$ & 0.766 & 0.507 & 0.167 & 0.712 & & & & & & & & & & & \\
\hline SQ & 0.853 & 0.583 & 0.195 & 0.159 & 0.763 & & & & & & & & & & \\
\hline FC & 0.802 & 0.549 & 0.320 & 0.240 & 0.167 & 0.741 & & & & & & & & & \\
\hline $\mathrm{EE}$ & 0.867 & 0.613 & 0.45 & 0.134 & 0.226 & 0.151 & 0.783 & & & & & & & & \\
\hline $\mathrm{PE}$ & 0.897 & 0.641 & 0.279 & 0.284 & 0.442 & 0.304 & 0.411 & 0.80 & & & & & & & \\
\hline HT & 0.759 & 0.502 & 0.257 & 0.252 & 0.422 & 0.282 & 0.326 & 0.521 & 0.70 & & & & & & \\
\hline HM & 0.750 & 0.521 & 0.194 & 0.169 & 0.291 & 0.220 & 0.253 & 0.336 & 0.342 & 0.72 & & & & & \\
\hline IQ & 0.810 & 0.630 & 0.462 & 0.208 & 0.392 & 0.221 & 0.501 & 0.38 & 0.371 & 0.316 & 0.79 & & & & \\
\hline SI & 0.869 & 0.691 & 0.091 & 0.081 & 0.088 & 0.030 & 0.056 & 0.006 & 0.034 & 0.065 & 0.038 & 0.83 & & & \\
\hline SATIS & 0.935 & 0.784 & 0.451 & 0.412 & 0.491 & 0.364 & 0.194 & 0.514 & 0.325 & 0.497 & 0.317 & 0.547 & 0.885 & & \\
\hline USE & 0.941 & 0.841 & 0.614 & 0.601 & 0.651 & 0.591 & 0.214 & 0.614 & 0.541 & 0.581 & 0.287 & 0.584 & 0.579 & 0.917 & \\
\hline Loyalty & 0.904 & 0.718 & 0.341 & 0.391 & 0.394 & 0.378 & 0.184 & 0.421 & 0.365 & 0.471 & 0.214 & 0.510 & 0.514 & 0.551 & 0.847 \\
\hline
\end{tabular}

Note: Diagonal values are squared roots of AVE/ off-diagonal values are the estimates of inter-correlation between the latent constructs. 


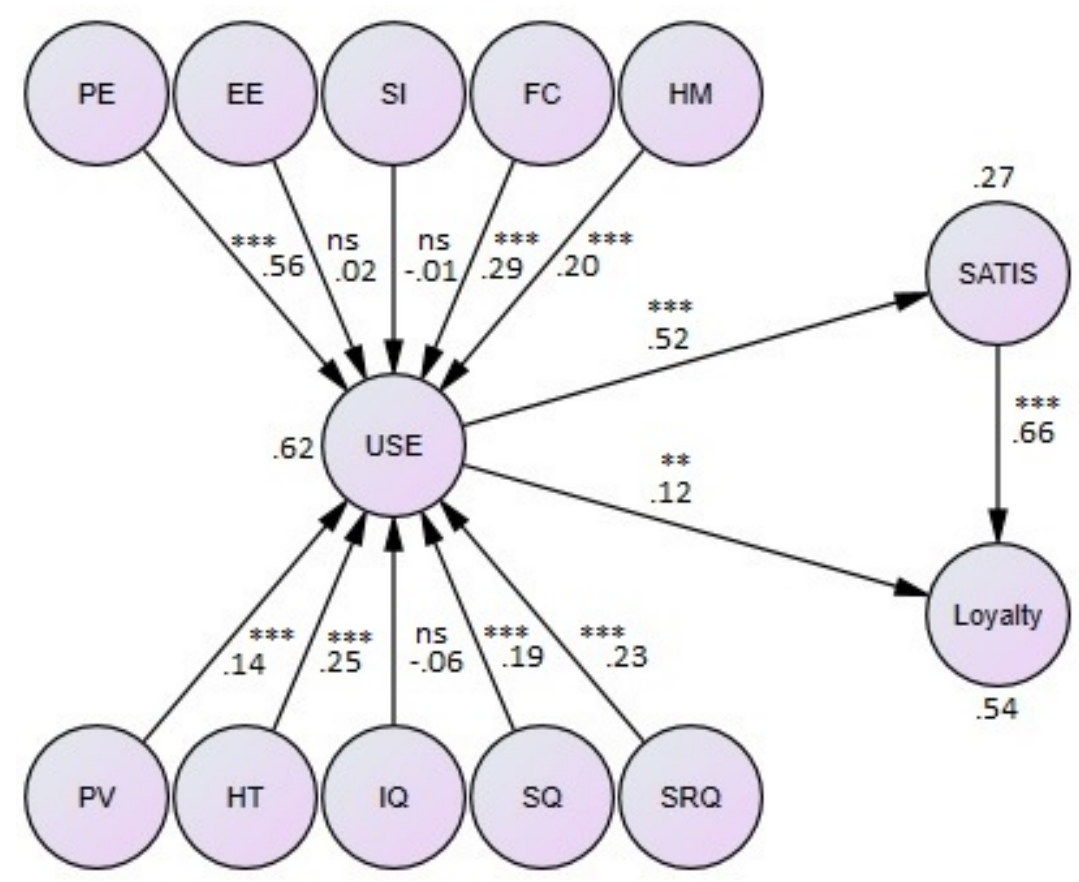

Figure 2: Validation of the Conceptual Model

[PE: Performance Expectancy, EE: Effort Expectancy, SI: Social Influence, FC: Facilitating Conditions, HM: Hedonic Motivation, PV: Price Value, HT: Habit, IQ: Information Quality, SQ: System Quality, SRQ: Service Quality, USE: Usage, SATIS: Satisfaction.

ns: $\mathrm{P}>0.05, *: \mathrm{P} \leq 0.05, * *: \mathrm{P} \leq 0.01, * * *: \mathrm{P} \leq 0.001]$

Table 4: Results of Standardised Estimates of Structural Model

\begin{tabular}{|l|l|l|l|l|l|}
\hline \multicolumn{2}{|c|}{ Hypothesised path } & Standardised estimate & P-value & Significance & VIF \\
\hline H1 & PE $\rightarrow$ USE & 0.56 & $* * *$ & YES & 1.587 \\
\hline H2 & EE $\rightarrow$ USE & 0.02 & 0.727 & NO & 0.874 \\
\hline H3 & SI $\rightarrow$ USE & -0.01 & 0.808 & NO & 0.954 \\
\hline H4 & FC $\rightarrow$ USE & 0.29 & $* * *$ & YES & 1.782 \\
\hline H5 & HM $\rightarrow$ USE & 0.20 & $* * *$ & YES & 2.024 \\
\hline H6 & PV $\rightarrow$ USE & 0.14 & $* * *$ & YES & 1.524 \\
\hline H7 & HT $\rightarrow$ USE & 0.25 & $* * *$ & YES & 2.354 \\
\hline H8 & SQ $\rightarrow$ USE & 0.19 & $* * *$ & YES & 2.124 \\
\hline H9 & SRQ $\rightarrow$ USE & 0.23 & $* * *$ & YES & 2.174 \\
\hline H10 & IQ $\rightarrow$ USE & -0.06 & 0.431 & NO & 0.851 \\
\hline H11 & USE $\rightarrow$ SATIS & 0.52 & $* * *$ & YES & 2.652 \\
\hline H12 & USE $\rightarrow$ Loyalty & 0.12 & $* *$ & YES & 2.031 \\
\hline H13 & SATIS $\rightarrow$ Loyalty & 0.66 & $* * *$ & YES & 2.684 \\
\hline
\end{tabular}

At the second stage of SEM, the structural model was tested to verify the conceptual model and its associated hypotheses. Similar to the measurement model, all fit indices of the structural model were observed to be within their acceptable levels as follows: GFI $=0.90$; $\mathrm{AGFI}=0.831 ; \mathrm{NFI}=0.922 ; \mathrm{CFI}=0.951$; and RMSEA $=0.068$ (Hair et al., 2010; Tabachnick and 
Fidell, 2007). The conceptual model was also able to predict a large portion of variance in the actual use behaviour with $\mathrm{R}^{2}$ value of 0.62 . A good $\mathrm{R}^{2}$ was also recorded for customer satisfaction (0.27) and customer loyalty (0.54). This, in turn, supports the predictive validity of the current study model.

The main causal paths were tested using path coefficient analyses as seen in Table 4 . The main factors of UTAUT2, namely PE $(\gamma=0.56 \mathrm{p}<0.000)$, PV $(\gamma=0.14, \mathrm{p}<0.000)$, FC $(\gamma=0.29$, $\mathrm{p}<0.000), \operatorname{HM}(\gamma=0.20, \mathrm{p}<0.000)$, and HT $(\gamma=0.25, \mathrm{p}<0.000)$, were found to have a significant impact on the actual use behaviour. However, EE was not proved to have any statistical association with actual use behaviour $(\gamma=0.020, p<0.727)$. As for the IS success model factor, both SQ $(\gamma=0.19, \mathrm{p}<0.000)$ and SRQ $(\gamma=0.23, \mathrm{p}<0.000)$ were confirmed to be significant predictors of the usage behaviour while IQ $(\gamma=-0.06, p<0.431)$ does not have any impact on this direction. The main causal paths beginning with usage and ending with satisfaction $(\gamma=0.52, \mathrm{p}<0.000)$ and loyalty $(\gamma=0.12, \mathrm{p}<0.002)$ were observed to have a significant coefficient value. In addition, the causal path between customer satisfaction and loyalty was also proved $(\gamma=0.66, p<0.000)$. However, there was no relationship between social influence and usage behaviour $(\gamma=-0.01, \mathrm{p}<0.808)$ Therefore, except for H2, H3, and H10, all research hypotheses $(\mathrm{H} 1, \mathrm{H} 4, \mathrm{H} 5, \mathrm{H} 6, \mathrm{H} 7, \mathrm{H} 8, \mathrm{H} 9, \mathrm{H} 11, \mathrm{H} 12$, and H13) were supported.

To ensure that multicollinearity problem does not exist between main dependent and independent constructs, variance inflation factors (VIF) were tested and all values extracted in this respect were noticed within their recommended level $(<10)$ as seen in Table 4 (Brace et al., 2003; Diamantopoulos and Siguaw, 2000).

\section{Discussion}

Banks worldwide have a challenge regarding their ability to keep their customers as loyal as possible. Therefore, different novel mechanisms (i.e. mobile banking) have been considered by banks to match the increasing customer demand for banking services. Indeed, current customers are expecting more in terms of when, how, and where they can get financial services (Leong et al., 2017). Mobile banking is one of the most effective tools to satisfy these high expectations from the customers' side (Oppong et al., 2014). Accordingly, banks always ask about the feasibility of such innovative channels in gaining the customers' satisfaction and loyalty. In fact, there is a limited number of studies that have addressed the 
related issues of mobile banking in the KSA. This, in turn, motivates the current study to examine how much implementing mobile banking could contribute to the level of Saudi bank customer satisfaction and loyalty.

In the line with what has been discussed in the conceptual model section and proved in the results section, it could be concluded that customer loyalty and satisfaction was observed to reach a high level among those customers who heavily use and positively perceive mobile banking as an effective banking channel to attain Internet services. Indeed, this study has successfully integrated factors from the UTAUT2 and IS success models into its model. The main results highly support the current model's predictive validity. For instance, about 0.62 , 0.27 , and 0.52 of variance was predicted in usage, satisfaction, and loyalty respectively.

According to the path coefficient analyses, five factors from UTAUT2 (PE, FC, HM, PV, and HT) and two factors from the IS success model (SQ and SRQ) were proved to have significant relationships with actual usage behaviour. As presented in the results section, PE was observed to be among the strongest factors predicting actual use behaviour. To put it differently, those customers who extensively use mobile are more likely to perceive such innovative channels as more productive and useful in their daily life. Mobile banking is associated with a high degree of mobility which enables customers to conveniently access banking services at any time and in any place. This is especially in light of the fact that the majority of customers do not have sufficient time to visit banks during the working day, and, therefore, they are looking at mobile banking as a good solution for such a problem. These results agree with what has been proved by prior literature on mobile banking as reported by Alalwan et al. (2017), Brown et al. (2003), Calisir and Gumussoy (2008), Dwivedi et al. (2017a), Dwivedi et al. (2017b), and Sripalawat et al. (2011).

Facilitating conditions have also received particular attention from customers who have used mobile banking. Using mobile banking accurately requires important resources (i.e. smart phones, Internet, mobile Internet services) (Baabdullah et al., 2017), and without the availability of such resources customers can not use mobile banking. This, in turn, makes the role of facilitating conditions more important for the users of mobile banking. Additionally, as a new technology, customers usually need support from banks either in terms of teaching them how they can safely and effectively use mobile banking or making available customer services at any time customers have problems in using mobile banking. Furthermore, the compatibility of mobile banking with other mobile applications that customers broadly use 
makes the impact of facilitating conditions more crucial as discussed by Alalwan et al. (2017). Such results are comparable with those of prior studies that have examined related issues of mobile banking (i.e. Alalwan et al., 2017; Lee and Chung, 2009; Rana et al., 2017; Wang and Shih, 2009; Yu, 2012; Zhou et al., 2010).

Saudi customers were also observed to be concerned regarding the monetary value that could be gained using mobile banking. This means that the usage rate of mobile banking reaches the highest level among those customers who perceive that its use can gain them more financial benefits in comparison to cost paid. As discussed by Venkatesh et al. (2012), using systems like mobile banking is not free, and the customer is requested to pay a direct cost to use such facilities as well as bearing the cost of purchasing important facilities and services (i.e. smart phone, $\mathrm{Wi}-\mathrm{Fi}$, and other mobile Internet services) to use mobile banking. Accordingly, customers usually engaged in a trade-off process between the cost of using mobile banking and the benefits recognized (Baabdullah et al., 2015). Such results are comparable with results extracted by prior studies like Alalwan et al. (2017) in Jordan and Kim et al. (2007) in their study examining adoption of mobile Internet.

The importance of the role of intrinsic utilities was proved through a strong relationship observed between hedonic motivation and actual use behaviour. To put it differently, bank customers are really encouraged to heavily use mobile banking by increasing the level of hedonic motivation (i.e. joy, enjoyment, playfulness) existing in the applying of such systems. Theoretically, different IS and information technology studies have discussed the role of intrinsic motivation alongside extrinsic utilities (see Davis et al., 1992; Van der Heijden, 2004; Venkatesh et al., 2012; Venkatesh, 2000). Different studies examining the adoption of mobile technology applications have tested and proved the importance of the role of hedonic motivation, such as Alalwan et al. (2017) and Kim et al. (2013).

The last significant factor in the UTAUT2 was habit which is able to predict the actual use behaviour of mobile banking. Saudi bank customers who formulate a habitual behaviour toward mobile banking were observed to heavily use mobile banking services. This could be due to the fact that as long as customers habitually use a new system, they have good experience and knowledge for using mobile banking, and this, in turn, reflects positively on the extent of how much customers actually use mobile banking. Indeed, individuals are recently more engaged in using their smart phones; accordingly, they are more likely to form this kind of habit toward different kinds of mobile applications, one of which is mobile 
banking. The role of habit has been confirmed by Ha et al. (2007) in their study examining the adoption of mobile games. In addition, Alalwan et al. (2018) recently proved the role of habit on the actual adoption of Internet banking by Jordanian customers.

Two factors from the IS success model, system quality and service quality, were found to have a significant impact on the usage of mobile banking. System quality was discussed by Delone and Mclean (2003) as one of the main aspects that individuals pay attention to once they are in the process of adopting and using new systems. This thought has been supported by the results of the current study. Accordingly, Saudi customers are more likely to be effective users of mobile banking if they perceive mobile banking systems can be enjoyed with a high degree of usability, availability, reliability, adaptability, and response time. Indeed, these technical characteristics are largely reflected in the customers' ability to successfully and accurately use new systems as reported by Delone and Mclean (2003), Laforet and Li (2005), Lee and Chung (2009), Shannon and Weaver (1998), and Zhou (2011).

As for the services quality, mobile banking is a new and very novel technology, and thus, customers need to have an adequate level of support. Indeed, the main dimensions of services quality (i.e. security/privacy, practicality, design/aesthetics, enjoyment, and sociality) are the focus of attention by customers as proposed by Arcand et al. (2017), Delone and McLean (2003), and Shih and Fang (2006) and statistically proved by the results of the current study. This, in turn, reveals the importance of the collaboration between different parties such as customer service at the bank, mobile service providers, the IS department at the bank, and Internet service providers to deliver a high quality of customer service. Such results are in line with what has been proved by prior studies over the related area of technology adoption and mobile technology (see Casalo et al., 2007; Changchit et al., 2017; Jun and Cai, 2001; Kshetri, 2016; Lee and Chung, 2009; Shih and Fang, 2004).

As proposed in the conceptual model, a significant relationship was proved between the actual usage of mobile banking and the level of customer satisfaction. Such results clearly indicate that those customers who extensively use mobile banking services will be more likely to be satisfied about the banks that provide such innovative channels. According to prior discussion regarding the role of performance expectancy, price value, and hedonic motivation, Saudi customers strongly perceive mobile banking as a more productive banking channel saving their time, money, and efforts, and they also really consider such a system as 
a source of hedonic benefits. This, in turn, explains why using mobile banking contributes to the level of customer satisfaction. By the same token, a strong correlation was observed between the actual use of mobile banking and customer loyalty. In this regard, those customers who heavily use mobile banking are more likely to continue dealing with their banks in future. This could be attributed to the strong relationship between the level of usage of mobile banking and customer satisfaction as discussed above. A direct relationship was also found between customer satisfaction and customer loyalty. All things considered suggest that implementation of mobile banking has been more crucial not only in terms of customer satisfaction but also in terms of customer loyalty. The results with regard to customer satisfaction and customer loyalty are in the line with what has been discussed and proposed by Delone and Mclean (2003), Chu et al. (2009), Chung and Kwon (2009), Ganguli and Roy (2011), Lin and Wang (2006), and Oppong et al. (2014).

However, three factors (effort expectancy, social influence, and information quality) in the conceptual model fail in predicting any variance in the usage of mobile banking. This means that Saudi customers are not concerned regarding the level of ease of use existing in mobile banking. According to the main profile characteristics of the current sample participants, most of them are well educated, younger, and have adequate experience with technology and the Internet. Thus, they are more likely to override any problem regarding the level of the complexity and difficulty of using mobile banking (Alalwan et al., 2017; Davis et al., 1989; Venkatesh et al., 2003; Venkatesh et al., 2012; Wessels and Drennan, 2010). This is in addition to the fact that all the participants of the current study sample are actual users of mobile banking, and therefore they have the necessary experience to cope with is system. In line with Venkatesh et al. (2003), the impact of effort expectancy is more likely to vanish as individuals have more experience of using the targeted technology. Theoretically, a number of different studies have noticed the non-significant impact of effort expectancy (i.e. Brown et al., 2003; Koenig-Lewis et al., 2010; Wessels and Drennan, 2010; Wu and Wang, 2005; Yu, 2012; Zhou et al., 2010).

By the same token, social influence does not predict any variance in the actual use of mobile banking. To say it differently, Saudi customers are less likely to depend on the information and suggestions coming from their social system in forming their decision to use mobile banking. As discussed by Venkatesh et al. (2003), there is less chance of customers being concerned about the support of the social system if they have a good experience in coping with technology. The participants of the current study sample are actual users and have a 
good experience of mobile banking. These results are no different from other studies that have examined the role of social influence (i.e. Alalwan et al., 2016; Alalwan et al., 2017; Alalwan et al., 2018; Curran and Meuter, 2007; Gerrard and Cunningham, 2003; Shih and Fang, 2004; Tan and Teo, 2000).

\subsection{Theoretical contributions}

This study contributes theoretically to the existing literature of M-Banking usage within the domain of Saudi Arabia for a number of reasons. Firstly, it produces new quantitative knowledge about the factors that influence the usage of Saudi customers of M-banking. As such, through the use of SEM for getting descriptive and inferential statistics, this study got reliable findings, which can be generalised to the targeted population (Urbach and Ahlemann, 2010). This is due to the capacity of SEM in producing an accurate calculation of probability distribution of observed data (Urbach and Ahlemann, 2010).

Secondly, this study tested the UTAUT2 model and IS success model in a new context (i.e. Saudi Arabia) and a new technological service (i.e. M-banking). This is compatible with Venkatesh et al.'s (2012) recommendations about testing UTAUT2 in new contexts and new IT services. Likewise, Delone and Mclean (2003) suggested extending the usage of the IS success model on new services.

Thirdly, the integration of two IT models (i.e. UTAUT2 and IS success) is unique in the literature as, to date, no such combination has been done internationally. This integration of the two models has contributed to increasing the predictive power of consumer usage of $\mathrm{M}$ Banking in Saudi Arabia.

\subsection{Implications to practice}

The findings of this study can be embraced by Saudi decision makers in order to increase the level of M-Banking usage among Saudi users. This is done by manipulating the effective variables from each model (UTAUT2 and IS Success Model) which were proved to have significant influence over usage, satisfaction, and loyalty among Saudi M-Banking users. Thus, decision makers and financial institutions should consider the roles of PE, FC, HM, PV, and HT from the UTAUT2 model as well as the roles of system quality and service quality from the IS success model in increasing the level of usage, satisfaction, and loyalty when using M-Banking. 
With regarding to controlling and amending system quality and service quality variables from the IS success model, financial institutions and banks should focus on increasing the level of quality of their systems such as supporting usability, availability, reliability, adaptability, and response time as antecedent conditions for maximising the level of M-Banking usage among users. Furthermore, banks should increase the level of service quality through continuous attention on maximising their overall support for M-Banking users at any time and under any circumstances. Through providing high service quality, issues of security/privacy would be guaranteed and uncompromised. This would lead to higher level of customer satisfaction and usage (Dwivedi et al., 2015). For instance, after using M-Banking for a number of payments in one day, the institutional bank can send a warning (checking) SMS that requests the user to send confirmation to the bank that he/she is the person who did the transactions. Furthermore, M-Banking users can request banks to deactivate their M-Banking accounts in case users do suspect that their mobiles got hijacked or lost. However, with regard to information quality, there is no requirement for the banks to focus on measuring semantic success, which is the core of information quality. The trivial effect of information quality over usage is due to the already substantial advancement in cases of sematic relationship in various technological services. Hence, customers would not be impacted by new changes in information quality (Hung and Hsu, 2013).

With regard to monitoring and controlling $\mathrm{PE}, \mathrm{FC}, \mathrm{HM}, \mathrm{PV}$, and $\mathrm{HT}$ variables from UTAUT2, it is essential to focus particularly on the role of PE, which has the highest level of influence over M-Banking usage among Saudis. Decision makers should highlight the importance of using M-Banking for attaining gains when performing various tasks. This assertion on the importance of M-Banking, such as the ability to access banking services in any remote place, would positively impact on beliefs of users towards using M-Banking. EE and SI do not have a substantial effect on M-Banking usage. This means that M-Banking users do care about tangible benefits such as PV, which is a trade-off between perceived benefits and monetary costs, rather than focusing on intangible matters such as SI, which is about being affected by others' beliefs. Hence, there is a practical necessity to increase the level of PV when using M-Banking.

Enhancing the level of PV could be achieved by convincing customers that adopting MBanking service will result in higher financial savings and time efficiency. Thus, instead of losing time and cost by travelling to banks' premises, the users can directly monitor their financial issues at any place in Saudi Arabia. Furthermore, the low effect of SI does overturn 
the common perception about the conservatist nature of the Saudi community, which asserts the traditional positive effect of social influence in this community on the beliefs of people as previously suggested by Hofstede (2003). Hence, banks and decision makers should consider that Saudi customers, particularly the youth, on middle-sized income, and educated, start being more individualistic when using highly individualistic IT services (i.e. M-Banking). FC should also be implemented in order to raise the level of personal customisation in $\mathrm{M}$ Banking services.

\subsection{Limitations and recommendations for future research}

This study adopts convenience sampling of Saudi M-Banking users. This may adversely impact the issue of generalisability to the whole population (Bhattacherjee, 2012). Furthermore, the findings indicated that the majority of respondents are youths, educated and on medium-sized income. Accordingly, this sample may not accurately reflect the targeted population (Farrokhi and Mahmoudi-Hamidabad, 2012). This is because the fact that is sample does dismiss other groups in the population such as old, non-educated, and highincome M-Banking users. Thus, the findings resulted from applying convenience sampling would not be applicable reliably on different demographic groups within the targeted population. In order to get a more representative sample to the whole population, future studies should extend to the whole geography of Saudi Arabia by including participants from urban and non-urban areas (Farrokhi et al., 2012).

The time horizon of this study was cross-sectional. This means that data were collected from each participant one time (Orlikowski and Baroudi, 1991). Unlike in longitudinal studies, the researcher is not able to duplicate the findings, and this, in turn, may reduce the reliability of the findings (Orlikowski and Baroudi, 1991). The importance of doing longitudinal studies in this type of research is that the habits of consumers change as time passes due to changes in technological services (Venkatesh and Davis, 2000). Future studies should implement longitudinal studies in order to re-collect the findings, particularly when considering the HT variable, which cannot be imagined or crystallised without having a period of time (Venkatesh and Davis, 2000).

Furthermore, the current study found that effort expectancy, social influence, and information quality have no impact on customer usage of M-Banking technology. This does not conform with other studies that examined the importance of the role of these three factors on the behaviour of people internationally and within the context of Saudi Arabia (e.g. Al-Husein 
and Sadi, 2015; Lee and Chung, 2009; Oliveira et al., 2014). Hence, future studies are motivated to re-examine the essential role of effort expectancy, social influence, and information quality for more investigation. In this regard, the important impact of culture should be considered by future studies. Indeed, culture has largely assured ensured its impact on customers' perception, attitudes, habit, and behaviour toward new systems (i.e. Al-Gahtani et al., 2007; Lee et al., 2007; Zhang et al., 2018). Accordingly, researchers could see the nature of Saudi culture and how it could moderate the impact of key predictors of adoption, satisfaction, and loyalty toward mobile banking. Further, a cross-cultural study between Saudi Arabia and other developed or developing countries could provide more clues regarding the impact of culture as conducted by Jaruwachirathanakul and Fink (2005) and Nilsson (2007).

Moreover, future research can include new variables such as perceived security and perceived privacy due to the importance of these two factors in financial dealings (Casalo et al., 2007). Likewise, integrations among other IT/IS models could be done, such as combining TaskTechnology Fit (TTF) Model. This novel integration between already-existing models contributes to testing the efficiency of this integration on particular IT technology in a certain context, which, in turn, would constitute a contribution to the current IT/IS literature. In addition, an integration of the UTAUT2 model and the IS success model can be adopted by future studies to be tested on new IT services other than M-Banking such as m-government, m-commerce, and other m-technologies, and this study can be done in various contexts (e.g. government, tourism, media, health and education).

\section{Conclusions}

As discussed at the beginning, this study was conducted with intention to see what the main factors that could affect the usage of mobile banking in the KSA. This is in addition to see how using such system could contribute to the banks in term of customer satisfaction and loyalty. Therefore, this study early realises the need of building a solid and comprehensive model covering the main aspects related to mobile banking adoption. So that, an integrated model based on UTAUT2 and IS success Model was proposed. So as to test the research model, an empirical study was conducted over the period between May and August in 2017 using self-administrative questionnaire which was allocated to a convenience sample of Saudi banking customers in the six largest cities in the KSA [Riyadh, Jeddah, Mecca, Medina, AlAhsa, and Ta'if]. SEM was then used to test the collected data, and the main results largely 
supported the proposed model which was able to predict of $62 \%$ and $54 \%$ of variance in usage and loyalty respectively. Further, except EE, SI, and IQ, the rest factors PE, FC, PV, HM, HT, SQ, and SRQ are supported to have a significant impact on the usage behaviour. A strong relationship was also supported between actual usage behaviour and customer satisfaction. Finally, customer loyalty was noticed to be strongly predicted by the role of both usage behaviour and satisfaction.

\section{References}

A. Asongu, S. and Nwachukwu, J. C. (2018). Comparative human development thresholds for absolute and relative pro-poor mobile banking in developing countries. Information Technology \& People, 31(1), 63-83.

Aboelmaged, M. and Gebba, T. R. (2013). Mobile banking adoption: an examination of technology acceptance model and theory of planned behavior. International Journal of Business Research and Development, 2(1).

Afshan, S. and Sharif, A. (2016). Acceptance of mobile banking framework in Pakistan. Telematics and Informatics, 33(2), 370-387.

Akturan, U. and Tezcan, N. (2012). Mobile banking adoption of the youth market: perceptions and intentions. Marketing Intelligence \& Planning, 30(4), 444-459.

Alalwan, A. A., Dwivedi, Y. K. and Rana, N. P. (2017). Factors influencing adoption of mobile banking by Jordanian bank customers: Extending UTAUT2 with trust. International Journal of Information Management, 37(3), 99-110.

Alalwan, A. A., Dwivedi, Y. K., Rana, N. P. and Algharabat, R. (2018). Examining factors influencing Jordanian customers' intentions and adoption of internet banking: Extending UTAUT2 with risk. Journal of Retailing and Consumer Services, 40, 125138.

Alalwan, A. A., Dwivedi, Y. K., Rana, N. P. and Williams, M. D. (2016). Consumer adoption of mobile banking in Jordan: Examining the role of usefulness, ease of use, perceived risk and self-efficacy. Journal of Enterprise Information Management, 29(1), 118139.

Alalwan, A. A., Rana, N. P., Dwivedi, Y. K., Lal, B. and Williams, M. D. (2015, October). Adoption of mobile banking in Jordan: Exploring demographic differences on customers' perceptions. In Conference on e-Business, e-Services and e-Society (pp. 13-23). Springer, Cham.

Alalwan, A. Dwivedi, Y. and Williams, M. (2014). Examining factors affecting customer intention and adoption of Internet banking in Jordan. In UK Academy for Information Systems Conference Proceedings.

Albawaba. (2017). Mobile Banking, Not Traditional Banking, Is What Saudi Customers Want: Infographic. Available at: https://www.albawaba.com/business/mobilebanking-saudi-arabia-infographic-1021314. Accessed date: 04.08.2018. 
Alfarani, L. A. (2015). Influences on the Adoption of Mobile Learning in Saudi Women Teachers in Higher Education. International Journal of Interactive Mobile Technologies, 9(2).

Al-Gahtani, S. S., Hubona, G. S. and Wang, J. (2007). Information technology (IT) in Saudi Arabia: Culture and the acceptance and use of IT. Information \& Management, 44(8), 681-691.

Al-Husein, M. and Sadi, M. A. (2015). Preference on the perception of mobile banking: A Saudi Arabian Perspective. European Online Journal of Natural and Social Sciences, 4(1), 161.

Al-Jabri, I. M. and Sohail, M. S. (2012). Mobile banking adoption: Application of diffusion of innovation theory. Journal of Electronic Commerce Research, 13 (4): 1-13.

Alkhaldi, A. N (2016). Adoption of Mobile Banking in Saudi Arabia: An Empirical Evaluation Study. International Journal of Managing Information Technology 8 (2):1-14.

Alsheikh, L. and Bojei, J. (2014). Determinants affecting customer's intention to adopt mobile banking in Saudi Arabia. International Arab Journal of e-Technology, 3(4), 210-219.

Al-Somali, S. A., Gholami, R. and Clegg, B. (2009). An investigation into the acceptance of online banking in Saudi Arabia. Technovation, 29(2), 130-141.

Al-Sukkar, A. S. (2005). The application of information systems in the Jordanian banking sector: A study of the acceptance of the internet. University of Wollongong Thesis Collection, 419.

Anderson, E. W. and Sullivan, M. W. (1993). The antecedents and consequences of customer satisfaction for firms. Marketing Science, 12(2), 125-143.

Anderson, J. C. and Gerbing, D. W. (1988). Structural equation modelling in practice: A review and recommended two-step approach. Psychological Bulletin, 103(3), 411423.

Arcand, M., PromTep, S., Brun, I. and Rajaobelina, L. (2017). Mobile banking service quality and customer relationships. International Journal of Bank Marketing, 35(7), 1068-1089.

Baabdullah, A. M. (2018a). Consumer adoption of Mobile Social Network Games (M-SNGs) in Saudi Arabia: The role of social influence, hedonic motivation and trust. Technology in Society, 53, 91-102.

Baabdullah, A. M. (2018b). Factors Influencing Adoption of Mobile Social Network Games (M-SNGs): The Role of Awareness. Information Systems Frontiers, 1-17. DOI: https://doi.org/10.1007/s10796-018-9868-1

Baabdullah, A. M., Alalwan, A. A. and Al Qadi, N. S. (2018). Evaluating the Current Situation of Mobile Services (M-Services) in the Kingdom of Saudi Arabia. In Emerging Markets from a Multidisciplinary Perspective (pp. 149-160). Springer, Cham.

Baabdullah, A. M., Alalwan, A. A., Rana, N. P., Dwivedi, Y. and Weerakkody, V. (2017). Assessing consumers' intention to adopt mobile internet services in the Kingdom of Saudi Arabia. Boston, MS: AMCIS. 
Baabdullah, A. M., Dwivedi, Y. K. and Williams, M. D. (2015). Understanding the adoption of mobile internet in the Saudi Arabian context: Results from a descriptive analysis. Open and Big Data Management and Innovation (pp. 95-106). Cham, Switzerland: Springer International Publishing.

Baptista, G. and Oliveira, T. (2015). Understanding mobile banking: The unified theory of acceptance and use of technology combined with cultural moderators. Computers in Human Behavior, 50, 418-430.

BBC. (2017). Mobile banking is saving us 'billions' in charges. Available at: http://www.bbc.co.uk/news/business-39290041. Accessed date: 08.10.2017.

Bhatiasevi, V. (2016). An extended UTAUT model to explain the adoption of mobile banking. Information Development, 32(4), 799-814.

Bhattacherjee, A. (2012). Social science research: Principles, methods, and practices. $2^{\text {nd }}$ edn. Florida, USA: Anol Bhattacherjee.

Brace, N., Kemp, R. and Snelgar, R. (2003). SPSS for psychologists: A guide to data analysis using SPSS for windows. (2. baskl). Hampshire: Palgrave: Macmillan.

Brislin, R. (1976). Comparative research methodology: Cross-cultural studies. International Journal of Psychology, 11(3), 215-229.

Brown, I., Cajee, Z., Davies, D. and Stroebel, S. (2003). Cell phone banking: predictors of adoption in South Africa - an exploratory study. International Journal of Information Management, 23(5), 381-394.

BT. (2017). Mobile banking is savings us billions in charges, new research claims. Available date: http://home.bt.com/tech-gadgets/tech-news/mobile-banking-saving-billionscharges-11364170689098. Accessed date: 08.10.2017.

Calisir, F. and Gumussoy, C. A. (2008). Internet banking versus other banking channels: Young consumers' view. International Journal of Information Management, 28(3), 215-221.

Casalo, L. V., Flavián, C. and Guinalíu, M. (2007). The role of security, privacy, usability and reputation in the development of online banking. Online Information Review, 31(5), 583-603.

Chae, M., Kim, J., Kim, H. and Ryu, H. (2002). Information quality for mobile internet services: A theoretical model with empirical validation. Electronic Markets, 12(1), $38-46$.

Changchit, C., Lonkani, R. and Sampet, J. (2017). Mobile Banking: Exploring Determinants of Its Adoption. Journal of Organizational Computing and Electronic Commerce, 27 (3). 239-26.

Choudrie, J., Junior, C. O., McKenna, B. and Richter, S. (2018). Understanding and conceptualising the adoption, use and diffusion of mobile banking in older adults: A research agenda and conceptual framework. Journal of Business Research, 88 (July), 449-465.

Chu, S. and Yao-bin, L. (2009, June). The effect of online-to-mobile trust transfer and previous satisfaction on the foundation of mobile banking initial trust. In 2009 Eighth International Conference on Mobile Business (pp. 1-6). IEEE. 
Chung, N. and Kwon, S. J. (2009). Effect of trust level on mobile banking satisfaction: a multi-group analysis of information system success instruments. Behaviour \& Information Technology, 28(6), 549-562.

Communication and Information Technology Commission (CITC). (2015). KSA ICT Indicators End of $Q 4$ 2015. Available at: http://www.citc.gov.sa/en/reportsandstudies/indicators/Indicators\%20of\%20Communi cations\%20and\%20Information\%20Techn/ICTIndicators-Q42015englishfinal.pdf. Accessed date: 30.09.2017.

Curran, J. M. and Meuter, M. L. (2007). Encouraging existing customers to switch to selfservice technologies: put a little fun in their lives. Journal of Marketing Theory and Practice, 15(4), 283-298.

Dabholkar, P.A. (1996). Consumer evaluations of new technology-based self-service options: an investigation of alternative models of service quality. International Journal of Research in Marketing, 13(1), 29-51.

Dancey, C. P. and Reidy, J. (2007). Statistics without maths for psychology. Pearson Education.

Davis, F. D. (1989). Perceived usefulness, perceived ease of use, and user acceptance of information technology. MIS Quarterly, 319-340.

Davis, F. D., Bagozzi, R. P. and Warshaw, P. R. (1992). Extrinsic and intrinsic motivation to use computers in the workplace 1. Journal of Applied Social Psychology, 22(14), 1111-1132.

Delone, W. H. and McLean, E. R. (2003). The DeLone and McLean model of information systems success: a ten-year update. Journal of Management Information Systems, 19(4), 9-30.

Diamantopoulos, A. and Siguaw, J. A. (2000). Introducing LISREL. London: Sage Publications Ltd.

Dwivedi, Y. and Irani, Z. (2009). Understanding the adopters and non-adopters of broadband. Communications of the ACM, 52(1), 122-125.

Dwivedi, Y. K., Kapoor, K. K., Williams, M. D. and Williams, J. (2013). RFID systems in libraries: An empirical examination of factors affecting system use and user satisfaction. International Journal of Information Management, 33(2), 367-377.

Dwivedi, Y. K., Kelly, G., Janssen, M., Rana, N. P., Slade, E. L. and Clement, M. (2018). Social Media: The Good, the Bad, and the Ugly. Information Systems Frontiers, 20(3), 419-423.

Dwivedi, Y. K., Rana N. P., Janssen, M., Lal, B., Williams, M.D. and Clement, R.M. (2017a). An Empirical Validation of a Unified Model of Electronic Government Adoption (UMEGA). Government Information Quarterly, 34(2), 211-230.

Dwivedi, Y. K., Rana, N. P., Jeyaraj, A., Clement, M. and Williams, M. D. (2017b). Reexamining the Unified Theory of Acceptance and Use of Technology (UTAUT): Towards a Revised Theoretical Model. Information Systems Frontiers. DOI: https://doi.org/10.1007/s10796-017-9774-y

Dwivedi, Y. K., Shareef, M. A., Simintiras, A. C., Lal, B. and Weerakkody, V. (2016). A generalised adoption model for services: A cross-country comparison of mobile health (m-health). Government Information Quarterly, 33(1), 174-187. 
Dwivedi, Y. K., Wastell, D., Laumer, S., Henriksen, H. Z., Myers, M. D., Bunker, D., ... and Srivastava, S. C. (2015). Research on information systems failures and successes: Status update and future directions. Information Systems Frontiers, 17(1), 143-157.

Exportgov. (2018). Saudi Arabia - information and communication technology. Available at: https://www.export.gov/article?id=Saudi-Arabia-information-technology. Accessed date: 04.08.2018.

Faria, M. G. (2012). Mobile banking adoption: A novel model in the Portuguese context. Universidade Nova de Lisboa.

Farrokhi, F. and Mahmoudi-Hamidabad, A. (2012). Rethinking convenience sampling: Defining quality criteria. Theory and Practice in Language Studies, 2(4), 784.

Fornell, C. and Larcker, D. F. (1981). Evaluating structural equation models with unobservable variables and measurement error. Journal of Marketing Research, 18(1), 39-50.

Ganguli, S. and Roy, S. K. (2011). Generic technology-based service quality dimensions in banking: Impact on customer satisfaction and loyalty. International Journal of Bank Marketing, 29(2), 168-189.

Gerrard, P. and Barton Cunningham, J. (2003). The diffusion of internet banking among Singapore consumers. International Journal of Bank Marketing, 21(1), 16-28.

Gupta, S. (2013). The mobile banking and payment revolution. European Financial Review, 2, 3-6.

Ha, I., Yoon, Y. and Choi, M. (2007). Determinants of adoption of mobile games under mobile broadband wireless access environment. Information \& Management, 44(3), 276-286.

Hair Jr., J. F., Black, W. C., Babin, B. J. and Anderson, R. E. (2010). Multivariate data analysis: A global perspective. $7^{\text {th }}$ edn. Pearson Education International.

Han, H., Park, A., Chung, N. and Lee, K. J. (2016). A near field communication adoption and its impact on Expo visitors' behavior. International Journal of Information Management, 36(6), 1328-1339.

Hanafizadeh, P., Behboudi, M., Koshksaray, A. and Tabar, M. (2014). Mobile-banking adoption by Iranian bank clients. Telematics and Informatics, 31(1), $62 \mathrm{e} 78$.

Harman, H. H. (1976). Modern Factor Analysis. $3^{\text {rd }}$ edn. Chicago, IL: University of Chicago Press.

Hidayat-ur-Rehman, I. (2014). Mobile Banking Adoption in Saudi Arabia. Asian Journal of Research in Banking and Finance, 4(10), 300-310.

Hofstede, G. (2003). Culture's consequences: Comparing values, behaviors, institutions and organizations across nations. Sage Publications.

Huili, Y. A. O. and Zhong, C. (2011). The analysis of influencing factors and promotion strategy for the use of mobile banking. Canadian Social Science, 7(2), 60-63.

Hung, Y. W. and Hsu, S. C. (2013, May). Understanding the Impacts of Information Quality, System Quality and Service Quality on Consumers' Satisfaction and Continuance Intention. In 2013 Fifth International Conference on Service Science and Innovation (ICSSI) (pp. 245-246). IEEE. 
Jahya, N. (2004). Factors that influence Muslim consumers' preference towards Islamic banking products or facilities: Theory of reasoned action. (Master's Thesis), University Sains Malaysia.

Jaruwachirathanakul, B. and Fink, D. (2005). Internet banking adoption strategies for a developing country: The case of Thailand. Internet Research, 15(3), 295-311.

Jun, M. and Cai, S. (2001). The key determinants of internet banking service quality: a content analysis. International Journal of Bank Marketing, 19(7), 276-291.

Kahn, B. K., Strong, D. M. and Wang, R. Y. (2002). Information quality benchmarks: product and service performance. Communications of the ACM, 45(4), 184-192.

Kapoor, K. K., Tamilmani, K., Rana, N. P., Patil, P., Dwivedi, Y. K. and Nerur, S. (2018). Advances in social media research: past, present and future. Information Systems Frontiers, 20(3), 531-558.

Kim, G., Shin, B. and Lee, H. G. (2009). Understanding dynamics between initial trust and usage intentions of mobile banking. Information Systems Journal, 19(3), 283-311.

Kim, H. W., Chan, H. C. and Gupta, S. (2007). Value-based adoption of mobile internet: an empirical investigation. Decision Support Systems, 43(1), 111-126.

Kim, H. W., Xu, Y. and Koh, J. (2004). A comparison of online trust building factors between potential customers and repeat customers. Journal of the Association for Information Systems, 5(10), 13.

Kim, Y. H., Kim, D. J. and Wachter, K. (2013). A study of mobile user engagement (MoEN): Engagement motivations, perceived value, satisfaction, and continued engagement intention. Decision Support Systems, 56, 361-370.

Koenig-Lewis, N., Palmer, A. and Moll, A. (2010). Predicting young consumers' take up of mobile banking services. International Journal of Bank Marketing, 28(5), 410e432.

Kohli, R., Devaraj, S. and Mahmood, M. A. (2004). Understanding determinants of online consumer satisfaction: A decision process perspective. Journal of Management Information Systems, 21(1), 115-136.

Kshetri, N. (2016). Big data's role in expanding access to financial services in China. International Journal of Information Management, 36(3), 297-308.

Kuisma, T., Laukkanen, T. and Hiltunen, M. (2007). Mapping the reasons for resistance to Internet banking: A means-end approach. International Journal of Information Management, 27(2), 75-85.

Laforet, S. and Li, X. (2005). Consumers' attitudes towards online and mobile banking in China. International Journal of Bank Marketing, 23(5), 362-380.

Laukkanen, T. (2007). Internet vs mobile banking: comparing customer value perceptions. Business Process Management Journal, 13(6), 788-797.

Laukkanen, T. and Lauronen, J. (2005). Consumer value creation in mobile banking services. International Journal of Mobile Communications, 3(4), 325-338.

Lee, I., Choi, B., Kim, J. and Hong, S. J. (2007). Culture-technology fit: Effects of cultural characteristics on the post-adoption beliefs of mobile Internet users. International Journal of Electronic Commerce, 11(4), 11-51. 
Lee, J., Lee, J. and Feick, L. (2001). The impact of switching costs on the customer satisfaction-loyalty link: mobile phone service in France. Journal of Services Marketing, 15(1), 35-48.

Lee, K. C. and Chung, N. (2009). Understanding factors affecting trust in and satisfaction with mobile banking in Korea: A modified DeLone and McLean's model perspective. Interacting with Computers, 21(5-6), 385-392.

Lee, M. C. (2009). Factors influencing the adoption of internet banking: An integration of TAM and TPB with perceived risk and perceived benefit. Electronic Commerce Research and Applications, 8(3), 130-141.

Lee, Y. K., Park, J. H., Chung, N. and Blakeney, A. (2012). A unified perspective on the factors influencing usage intention toward mobile financial services. Journal of Business Research, 65(11), 1590-1599.

Leong, C., Tan, B., Xiao, X., Tan, F. T. C. and Sun, Y. (2017). Nurturing a FinTech ecosystem: The case of a youth microloan startup in China. International Journal of Information Management, 37(2), 92-97.

Liébana-Cabanillas, F., Marinković, V. and Kalinić, Z. (2017). A SEM-neural network approach for predicting antecedents of $\mathrm{m}$-commerce acceptance. International Journal of Information Management, 37(2), 14-24.

Limayem, M., Hirt, S. G. and Cheung, C. M. (2007). How habit limits the predictive power of intention: The case of information systems continuance. MIS Quarterly, 705-737.

Lin, H. F. (2011). An empirical investigation of mobile banking adoption: The effect of innovation attributes and knowledge-based trust. International Journal of Information Management, 31(3), 252-260.

Lin, H. H. and Wang, Y. S. (2006). An examination of the determinants of customer loyalty in mobile commerce contexts. Information \& Management, 43(3), 271-282.

Malaquias, F., Malaquias, R., \& Hwang, Y. (2018). Understanding the determinants of mobile banking adoption: A longitudinal study in Brazil. Electronic Commerce Research and Applications, 30, 1-7.

Martins, G., Oliveira, T. and Popovic, A. (2014) Understanding the Internet banking adoption: A unified theory of acceptance and use of technology and perceived risk application. International Journal of Information Management, 34(1), 1-13.

Masrek, M. N. and Razali, M. H. (2013, December). Antecedents and impacts of mobile banking transactions: a case of malaysian consumers. In Advanced Computer Science Applications and Technologies (ACSAT), 2013 International Conference on (pp. 401405). IEEE.

Mehrad, D. and Mohammadi, S. (2017). Word of Mouth impact on the adoption of mobile banking in Iran. Telematics and Informatics, 34(7), 1351-1363.

Nilsson, D. (2007). A cross-cultural comparison of self-service technology use. European Journal of Marketing, 41(3/4), 367-381.

Njenga, K. and Ndlovu, S. (2012, October). On rational choice, risk and utility in mobile banking. In Sustainable e-Government and e-Business Innovations (ELEADERSHIP), 2012 e-Leadership Conference on (pp. 1-9). IEEE.

Nunnally, J. C. (1978). Psychometric theory. New York, NY: McGraw-Hill. 
Oliveira, T., Faria, M., Thomas, M. A. and Popovic, A. (2014). Extending the understanding of mobile banking adoption: when UTAUT meets TTF and ITM. International Journal of Information Management, 34(5), 689e703.

Oppong, P., Adjei, H. and Poku, K. (2014). The Role of Information Technology in Building Customer Loyalty in Banking: (A Case Study of Agricultural Development Bank Ltd., SUNYANI). British Journal of Marketing Studies, August, 2(4), 9-29.

Orlikowski, W. J. and Baroudi, J. J. (1991). Studying information technology in organizations: Research approaches and assumptions. Information Systems Research, 2(1), 1-28.

Ozturk, A. B., Bilgihan, A., Nusair, K. and Okumus, F. (2016). What keeps the mobile hotel booking users loyal? Investigating the roles of self-efficacy, compatibility, perceived ease of use, and perceived convenience. International Journal of Information Management, 36(6), 1350-1359.

Park, J., Yang, S. and Lehto, X. (2007). Adoption of mobile technologies for Chinese consumers. Journal of Electronic Commerce Research, 8(3), 196.

Peters, T., Işık, Ö., Tona, O. and Popovič, A. (2016). How system quality influences mobile BI use: the mediating role of engagement. International Journal of Information Management, 36(5), 773-783.

Podsakoff, P. M., MacKenzie, S. B., Lee, J. Y. and Podsakoff, N. P. (2003). Common method biases in behavioral research: A critical review of the literature and recommended remedies. Journal of Applied Psychology, 88 (5), 879.

Raleting, T. and Nel, J. (2011). Determinants of low-income non-users' attitude towards WIG mobile phone banking: evidence from South Africa. African Journal of Business Management, 5(1), 212-223.

Rana, N. P., Dwivedi, Y. K. and Williams, M. D. (2015). A meta-analysis of existing research on citizen adoption of e-government. Information Systems Frontiers, 17(3), 547-563.

Rana, N. P., Dwivedi, Y. K., Lal, B., Williams, M. D. and Clement, M. (2017). Citizens' adoption of an electronic government system: towards a unified view. Information Systems Frontiers, 19(3), 549-568.

Rana, N. P., Dwivedi, Y. K., Williams, M. D. and Weerakkody, V. (2016). Adoption of online public grievance redressal system in India: Toward developing a unified view. Computers in Human Behavior, 59, 265-282.

Rod, M., Ashill, N. J., Shao, J. and Carruthers, J. (2009). An examination of the relationship between service quality dimensions, overall internet banking service quality and customer satisfaction: A New Zealand study. Marketing Intelligence \& Planning, 27(1), 103-126.

Roy, P. K., Singh, J. P., Baabdullah, A. M., Kizgin, H. and Rana, N. P. (2018). Identifying reputation collectors in community question answering (CQA) sites: Exploring the dark side of social media. International Journal of Information Management, 42, 2535.

Safeena, R., Date, H., Kammani, A. and Hundewale, N. (2012). Technology adoption and Indian consumers: study on mobile banking. International Journal of Computer Theory and Engineering, 4(6), 1020. 
Sait, S. M. and Al-Tawil, K. M. (2007). Impact of internet usage in Saudi Arabia: A social perspective. International Journal of Information Technology and Web Engineering (IJITWE), 2(2), 81-115.

Saleem, Z. and Rashid, K. (2011). Relationship between customer satisfaction and mobile banking adoption in Pakistan. International Journal of Trade, Economics and Finance, 2(6), 537e543.

Sampaio, C. H., Ladeira, W. J. and Santini, F. D. O. (2017). Apps for mobile banking and customer satisfaction: a cross-cultural study. International Journal of Bank Marketing, 35(7), 1133-1153.

Selnes, F. and Hansen, H. (2001). The potential hazard of self-service in developing customer loyalty. Journal of Service Research, 4(2), 79-90.

Shaikh, A. A. and Karjaluoto, H. (2015). Mobile banking adoption: A literature review. Telematics and Informatics, 32(1), 129-142.

Shamdasani, P., Mukherjee, A. and Malhotra, N. (2008). Antecedents and consequences of service quality in consumer evaluation of self-service internet technologies. The Service Industries Journal, 28(1), 117-138.

Shannon, C. E. and Weaver, W. (1998). The mathematical theory of communication. University of Illinois Press.

Shareef, M. A., Baabdullah, A., Dutta, S., Kumar, V. and Dwivedi, Y. K. (2018). Consumer adoption of mobile banking services: An empirical examination of factors according to adoption stages. Journal of Retailing and Consumer Services, 43(July), 54-67.

Shareef, M. A., Dwivedi, Y. K., Kumar, V. and Kumar, U. (2017). Content design of advertisement for consumer exposure: Mobile marketing through short messaging service. International Journal of Information Management, 37(4), 257-268.

Shareef, M. A., Dwivedi, Y. K., Stamati, T. and Williams, M. D. (2014). SQ mGov: a comprehensive service-quality paradigm for mobile government. Information Systems Management, 31(2), 126-142.

Sharma, S. K., Govindaluri, S. M., Al-Muharrami, S. and Tarhini, A. (2017). A multianalytical model for mobile banking adoption: A developing country perspective. Review of International Business and Strategy, 27(1), 133-148.

Shih, Y. and Fang, K. (2004). The use of a decomposed theory of planned behaviour to study internet banking in Taiwan. Internet Research, 14(3), 213-223.

Shih, Y. and Fang, K. (2006). Effects of network quality attributes on customer adoption intentions of internet banking. Total Quality Management. 17(1), 61-77.

Singh, S. and Srivastava, R. K. (2018). Predicting the intention to use mobile banking in India. International Journal of Bank Marketing, 36(2), 357-378.

Slade, E. L., Dwivedi, Y. K., Piercy, N. C. and Williams, M. D. (2015). Modeling consumers' adoption intentions of remote mobile payments in the United Kingdom: extending UTAUT with innovativeness, risk, and trust. Psychology \& Marketing, $32(8), 860-873$.

Slade, E., Williams, M., Dwivedi, Y. and Piercy, N. (2015). Exploring consumer adoption of proximity mobile payments. Journal of Strategic Marketing, 23(3), 209-223. 
Sripalawat, J., Thongmak, M. and Ngramyarn, A. (2011). M-banking in metropolitan Bangkok and a comparison with other countries. Journal of Computer Information Systems, 51(3), 67-76.

Statista. (2018a). Number of mobile phone internet users in Saudi Arabia from 2015 to 2022 (in millions). Available at: https://www.statista.com/statistics/558821/ number-ofmobile-internet-user-in-saudi-arabia, Accessed date: 04.08.2018.

Statista. (2018b). Share of respondents who are interested in online banking services in Saudi Arabia in October 2016, by offer). Available at: https://www.statista.com/statistics/741129/saudi-arabia-interest-in-online-bankingservices-by-offer/. Accessed date: 04.08.2018.

Tabachnick, B. G. and Fidell, L. S. (2007). Using multivariate statistics. Boston: Pearson Education.

Tam, C. and Oliveira, T. (2017). Understanding mobile banking individual performance: The DeLone \& McLean model and the moderating effects of individual culture. Internet Research, 27(3), 538-562.

Tan, M. and Teo, T. S. (2000). Factors influencing the adoption of Internet banking. Journal of the AIS, 1 (1es), 5.

The EY GCC Digital Banking Report. (2015). Where your customers want you to be. Available at: http://www.ey.com/Publication/vwLUAssets/EY-GCC-digital-bankingreport-2015/\$FILE/EY-GCC-digital-banking-report-2015.pdf. Accessed date: 27.09.2017.

Upadhyay, P. and Jahanyan, S. (2016). Analyzing user perspective on the factors affecting use intention of mobile based transfer payment. Internet Research, 26(1), 38-56.

Urbach, N. and Ahlemann, F. (2010). Structural equation modeling in information systems research using partial least squares. JITTA: Journal of Information Technology Theory and Application, 11(2), 5.

Van der Heijden, H. (2004). User acceptance of hedonic information systems. MIS Quarterly, 695-704.

Venkatesh, V. (2000). Determinants of perceived ease of use: Integrating control, intrinsic motivation, and emotion into the technology acceptance model. Information Systems Research, 11(4), 342-365.

Venkatesh, V. and Davis, F. D. (2000). A theoretical extension of the technology acceptance model: Four longitudinal field studies. Management Science, 46(2), 186-204.

Venkatesh, V., Morris, M. G., Davis, G. B. and Davis, F. D. (2003). User acceptance of information technology: Toward a unified view. MIS quarterly, 425-478.

Venkatesh, V., Thong, J. and Xu, X. (2012). Consumer acceptance and use of information technology: Extending the unified theory of acceptance and use of technology. MIS Quarterly, 36(1), 157-178.

Wang, Y. S. and Shih, Y. W. (2009). Why do people use information kiosks? A validation of the Unified Theory of Acceptance and Use of Technology. Government Information Quarterly, 26(1), 158-165.

Warsame, M. H. and Ireri, E. M. (2018). Moderation effect on mobile microfinance services in Kenya: An extended UTAUT model. Journal of Behavioral and Experimental Finance, 18 (July), 67-75. 
Wessels, L. and Drennan, J. (2010). An investigation of consumer acceptance of M-banking. International Journal of Bank Marketing, 28(7), 547-568.

Williams, M. D., Rana, N. P. and Dwivedi, Y. K. (2015). The unified theory of acceptance and use of technology (UTAUT): a literature review. Journal of Enterprise Information Management, 28(3), 443-488.

World Bank. (2017). Mobile Cellular Subscriptions (per 100 people). Available at: https://data.worldbank.org/indicator/IT.CEL.SETS.P2. Accessed date: 27.09.2017.

$\mathrm{Wu}$, J. H. and Wang, S. C. (2005). What drives mobile commerce?: An empirical evaluation of the revised technology acceptance model. Information \& Management, 42(5), 719729.

Xiong, S. (2013, November). Adoption of mobile banking model based on perceived value and trust. In Information Management, Innovation Management and Industrial Engineering (ICIII), 2013 6th International Conference on (Vol. 1, pp. 632-635). IEEE.

Yiu, C. S., Grant, K. and Edgar, D. (2007). Factors affecting the adoption of Internet Banking in Hong Kong-implications for the banking sector. International Journal of Information Management, 27(5), 336-351.

Yu, C. S. (2012). Factors affecting individuals to adopt mobile banking: Empirical evidence from the UTAUT model. Journal of Electronic Commerce Research, 13(2), 104.

Zeithaml, V. A., Berry, L. L. and Parasuraman, A. (1996). The behavioral consequences of service quality. The Journal of Marketing, 31-46.

Zhang, Y., Weng, Q. and Zhu, N. (2018). The relationships between electronic banking adoption and its antecedents: a meta-analytic study of the role of national culture. International Journal of Information Management, 40, 76-87.

Zhou, T. (2011). An empirical examination of initial trust in Mobile banking. Internet Research, 21(5), 527-540.

Zhou, T. (2012b). Examining mobile banking user adoption from the perspectives of trust and flow experience. Information Technology and Management, 13(1), 27-37.

Zhou, T., Lu, Y. and Wang, B. (2010). Integrating TTF and UTAUT to explain mobile banking user adoption. Computers in Human Behavior, 26(4), 760-767. 


\section{Appendix: Measurement Items}

\begin{tabular}{|c|c|c|c|}
\hline Constructs & & Items & Sources \\
\hline \multirow{4}{*}{$\begin{array}{l}\text { Performance } \\
\text { Expectancy }\end{array}$} & PE1 & I find Mobile banking useful in my daily life. & \multirow[t]{25}{*}{ Venkatesh et al. (2012) } \\
\hline & PE2 & Using Mobile banking increases my chances of achieving tasks that are important to me. & \\
\hline & PE3 & Mobile banking helps me accomplish tasks more quickly. & \\
\hline & PE4 & Using Mobile banking increases my productivity. & \\
\hline \multirow[t]{4}{*}{ Effort Expectancy } & EE1 & Learning how to use Mobile banking is easy for me. & \\
\hline & EE2 & My interaction with Mobile banking is clear and understandable. & \\
\hline & EE3 & I find Interne Mobile banking easy to use. & \\
\hline & EE4 & It is easy for me to become skilful at using Mobile banking. & \\
\hline \multirow{3}{*}{ Social Influence } & SI1 & People who are important to me think that I should use Mobile banking. & \\
\hline & SI2 & People who influence my behaviour think that I should use Mobile banking. & \\
\hline & SI3 & People whose opinions that I value prefer that I use Mobile banking. & \\
\hline \multirow{4}{*}{$\begin{array}{l}\text { Facilitating } \\
\text { Conditions }\end{array}$} & FC1 & I have the resources necessary to use Mobile banking. & \\
\hline & FC2 & I have the knowledge necessary to use Mobile banking. & \\
\hline & FC3 & Mobile banking is compatible with other technologies I use. & \\
\hline & FC4 & I can get help from others when I have difficulties using Mobile banking. & \\
\hline \multirow{3}{*}{$\begin{array}{l}\text { Hedonic } \\
\text { Motivation }\end{array}$} & HM1 & Using Mobile banking is fun. & \\
\hline & HM2 & Using Mobile banking is enjoyable. & \\
\hline & HM3 & Using Mobile banking is entertaining. & \\
\hline \multirow[t]{3}{*}{ Price Value } & PV1 & Mobile banking is reasonably priced. & \\
\hline & PV2 & Mobile banking is good value for the money. & \\
\hline & PV3 & At the current price, Mobile banking provides good value. & \\
\hline \multirow[t]{4}{*}{ Habit } & HT1 & The use of Mobile banking has become a habit for me. & \\
\hline & HT2 & I am addicted to using Mobile banking. & \\
\hline & HT3 & I must use Mobile banking. & \\
\hline & HT4 & Using Mobile banking has become natural to me. & \\
\hline \multirow[t]{5}{*}{ Usage } & USE1 & Balance enquiries and downloaded bank statements. & \multirow{5}{*}{$\begin{array}{l}\text { Curran and Meuter (2007), Martins et al. (2014) } \\
\text { and Zhou et al. (2010) }\end{array}$} \\
\hline & USE2 & Funds transfer. & \\
\hline & USE3 & Requesting cheque book or bank certificates. & \\
\hline & USE4 & Paying bills. & \\
\hline & USE5 & Request increase in credit card(s) limit or pay any balance due. & \\
\hline Information & IQ1 & Mobile banking provides me with information relevant to my needs. & Kim et al. (2004) and Zhou (2011) \\
\hline
\end{tabular}




\begin{tabular}{|c|c|c|c|}
\hline \multirow[t]{4}{*}{ Quality } & IQ2 & Mobile banking provides me with sufficient information. & \\
\hline & IQ3 & Mobile banking provides me with accurate information. & \\
\hline & IQ4 & Mobile banking provides me with up-to-date information. & \\
\hline & IQ5 & Mobile banking will provide relevant information about transactions. & \\
\hline \multirow{5}{*}{ System Quality } & SQ1 & Mobile banking quickly loads all the text and graphics. & \\
\hline & SQ2 & Mobile banking is user friendly. & \\
\hline & SQ3 & Mobile banking is easy to navigate & \\
\hline & SQ4 & Mobile banking is visually attractive. & \\
\hline & SQ5 & I would find Mobile banking secure enough to conduct my banking transactions. & \\
\hline \multirow{3}{*}{ Service Quality } & SRQ1 & The level of service quality I receive from Mobile banking is high. & \multirow[t]{3}{*}{ Dabholkar (1996) and Shamdasani et al. (2008) } \\
\hline & SRQ2 & The quality of service I receive from Mobile banking is excellent. & \\
\hline & SRQ3 & Mobile banking provides a high level of service quality. & \\
\hline \multirow[t]{5}{*}{ Satisfaction } & SATIS1 & I am generally pleased with Mobile banking services. & \multirow{5}{*}{$\begin{array}{l}\text { Anderson and Sullivan (1993), Kohli et al. (2004), } \\
\text { Lee and Chung (2009) and Rod et al. (2009) }\end{array}$} \\
\hline & SATIS2 & I am very satisfied with Mobile banking services. & \\
\hline & SATIS3 & I am happy with Mobile banking. & \\
\hline & SATIS4 & I am satisfied with the way that Mobile banking has carried out transactions. & \\
\hline & SATIS5 & Overall, I was satisfied with Mobile banking. & \\
\hline \multirow[t]{3}{*}{ Loyalty } & Loyalty1 & I will recommend using Mobile banking to other people. & \multirow{3}{*}{$\begin{array}{l}\text { Lee and Chung (2009), Selnes and Hansen (2001) } \\
\text { and Zeithaml et al. (1996) }\end{array}$} \\
\hline & Loyalty2 & I intend to continue using Mobile banking. & \\
\hline & Loyalty3 & I prefer using Mobile banking above other banking channels. & \\
\hline
\end{tabular}

